\title{
El hombre ante Dios
}

\section{Ser humano y revelación según Karl Rahner}

La tarea de este trabajo ha consistido en exponer la teoría de Rahner sobre la innata facultad del hombre para entender una comunicación de Dios, que será Dios mismo, y entenderla como tal, sin rebajar un ápice lo que Dios quiera comunicar. Se ha tratado de ver, según Rahner, la disposición del hombre para una revelación total de la infinitud de Dios, qué hay en el hombre que le haga depositario de la manifestación total y amorosa del ser de Dios; si esa revelación que proclama la fe cristiana no será algo superfluo, vista de forma filosófica, la pequeñez y necesaria contingencia de la naturaleza humana, o puede ser algo, un don de Dios, que responde a las perspectivas del horizonte humano del conocimiento, don que la constitución natural del hombre puede recibir, reconociéndolo en su procedencia sobrenatural y en su mensaje salvífico. El tema central será ese, la capacidad del hombre ante la revelación, que será completado con la reflexión de Rahner sobre la revelación en sí misma.

La revelación de Dios ha sido un tema importantísimo a lo largo de toda la historia de la teología católica. El fundamento del cristianismo estaba precisamente en la manifestación de Dios al hombre, a través de la revelación especial que resulta de la encarnación de Dios en el hombre Jesús, que forma una realidad humano-divina que alumbra el ser misericordioso de Dios y la divinización que éste produce en su contacto con el hombre. Se había, pues, hablado mucho sobre la gracia indebida de Dios al hombre, que no la merecía por sus pecados, pero no por tanto sobre la consecuencia indirecta que ésta suponía en el hombre. Es decir, si Dios se dirigía amorosamente al hombre, donándosele incondicionalmente para llamarlo a la comunión con él, sería porque en el hombre había algo que le habilitaba para escuchar la interpelación reveladora divina, porque el hombre podía oír la palabra de Dios.

Este desvelar la dignidad del hombre que proviene de su capacidad para atender a una revelación de Dios es uno de los méritos de Rahner, que, dentro de la corriente renovadora de la teología del siglo $\mathrm{XX}$, ha retomado para ello la 
doctrina de los Padres y ha aceptado la dinámica interna del rico pensamiento escolástico, superando los rígidos esquemas que estábleciera la última escolástica, que se mantenían vigentes en los primeros compases de este siglo. La revelación había quedado reducida a verdades que Dios comunicaba y ante las que al hombre sólo quedaba el asentir como fe. Eran superiores al entendimiento humano y, a pesar de estar reveladas, el hombre seguía sin comprenderlas más que como misterios, de modo que su actitud debía ser creerlas basado en el ser de Dios, verdad absoluta, que no puede engañarse ni engañarnos. Pero si la revelación de Dios, por la definición propia que lleva la palabra, era una manifestación de Dios al hombre, algo habría en el hombre que no dejaba caer en saco roto esa comunicación. Si Dios se manifestaba al hombre sería porque el hombre, de alguna manera, podía verlo. El cómo de esa potencia del hombre hacia Dios que dilucida el pensamiento de Rahner es lo que trata de presentar este trabajo.

Para ello se han tomado como eje los libros de Karl Rahner «Espíritu en el mundo», «Oyente de la palabra» y la primera mitad de «Curso fundamental sobre la fe», y se ha seguido el esquema básico de «Oyente de la palabra» *. «Espíritu en el mundo» versa como dice el subtítulo sobre la «metafísica del conocimiento finito según santo Tomás de Aquino». Es un estudio, partiendo de santo Tomás, sobre el conocimiento del hombre, del que se afirmará ser abierto a una amplitud sin límites, o espíritu, pero condicionado siempre para ello por lo sensible, o mundo, en una intrínseca interdependencia mutua. Estas conclusiones sobre la estructura del conocer humano son recogidas en "Oyente de la Palabra» para ponerlas en relación a una posible revelación de Dios. Si Dios se autorrevelase al hombre encontraría en su conocimiento una facultad adaptada positivamente, por su amplitud ilimitada, para recibir la infinitud de la automanifestación de Dios, y ello a pesar de la finitud mundana del hombre, pues ésta era la que impulsaba al espíritu a encontrarse a sí mismo. "Curso fundamental sobre la fe», concebido por Rahner como un resumen de toda su teología, trata en su grado quinto sobre la revelación como don de Dios al hombre, sirviendo como contrapunto de fe a los logros metafísicos anteriores. En este mismo sentido han servido las opiniones de Rahner

* RAHnER, K., Espíritu en el mundo, Herder, Barcelona 1963.- RAHner, K., Oyente de la palabra, Herder, Barcelona 1967.- RAHNER, K., Curso fundamental sobre la fe, Herder, Barcelona 1979.- RAHNER, K., «Sobre el concepto de misterio en la teología católica», en Escritos de Teología, IV, Taurus, Madrid 1961.- RAHNER, K., «Sobre la relación entre la naturaleza y la gracia», en Escritos de Teología, I, Taurus, Madrid 1961.- RAHNER, K., en Sacramentum mundi, Herder, Barcelona 1973: «Existencia sobrenatural», III; «Potencia obediencial», V; «Revelación», VI; «Gracia», III.- GARCIA-MURGA, J.R., Intimidad con Dios y servicio al prójimo, Gregoriana, Madrid 1968.- LehmanN, K., «Karl Rahner», en Bilancio della teologia del XX secolo, IV, Città nuova editrice, Roma 1972.- RAHNER, K., La grazia come centro dell'esistenza umana, Edizioni Paoline, Catania 1974. 
sobre gracia, naturaleza, salvación, que expone en «Escritos de teología» y «Sacramentum mundi».

El lenguaje que Rahner emplea en sus escritos no es fácil en absoluto. Exige una lectura lenta y concentrada, con frecuentes relecturas en algunos pasajes, debido a la densidad de su expresión y a la concatenación y complejidad de sus conceptos, que se asientan e implican unos en otros. Pero poco a poco se va entrando en el mundo rahneriano y se van iluminando mutuamente sus asertos en la estricta lógica que sigue, de tradición aristotélica. A medida que se asimilan sus ideas va creciendo la admiración por su especulación teológica, a pesar de que continúe siendo su lectura un poco fatigosa. Cuando se trata, a continuación, de explicar a Rahner no se puede evitar un cierto contagio de su forma de decir, por la fascinación que ejercen sus frases paradójicas repletas de matices, y se sigue la dialéctica convincente de su expresión, y quizá también su longitud.

\section{EL HOMBRE COMO «ESPÍRITU»}

Tradicionalmente, al hablar de la revelación, se partía siempre de la idea de Dios que decía, manifestaba, algo al hombre, necesario para su salvación y que éste, dada la limitación de su ser y la ilimitación divina, no podía alcanzar de ninguna manera con sus solas fuerzas. De este modo se entendía por revelación su contenido, aquellas verdades vitales para la salvación humana, don gratuito de Dios, pues el hombre no las lograba por sí mismo, y siempre ciertas por su origen divino. Que Dios podía revelar algo al hombre se consideraba lógico, sin problemas, por la omnipotencia divina, ante la que nada es imposible. Pero poco se pensó en el sentido primigenio de revelación como acercamiento de Dios al hombre, y en el hombre como receptor de la revelación en modo concreto, aunque de manera implícita, las bases para entender esa disposición divina y cualidad humana ya habían sido consideradas por la patrística y la primera escolástica al hablar de las semillas divinas que hay en el hombre y de la tendencia innata de éste a la felicidad y autorrealización.

Sin embargo, la reflexión sistemática sobre la capacidad del hombre para escuchar la revelación de Dios se imponía, si se quería entender cómo el hombre podía obedecer una comunicación de Dios; y de la misma manera era necesario comprender la revelación en su raíz fundante y única, en Dios mismo, más que en sus expresiones externas, como correspondiente a la capacidad del ser del hombre dicha, estructural y prerrefleja, anterior a la concreción categorial de la revelación ${ }^{1}$.

1. Éste es el intento, creo conseguido, del libro de Rahner «Oyente de la palabra», que mantendrá en sus obras posteriores con acentos diversos. 
Que el hombre es «espíritu» designa, en el lenguaje corriente, la cualidad humana que supera la naturaleza, a la que también pertenece el hombre, esto es, la particularidad de su mente, su conocimiento y libertad, por la que el hombre se contrapone al mundo en que vive y se proyecta en él de modo imprevisible, aunque siempre dentro de una básica dependencia.

En esta cualidad que distingue al hombre del entorno experimental en que se encuentra ve Rahner la apertura esencial del hombre hacia Dios, la capacidad humana constitutiva de entenderle, en cierta manera, y, por ello, la capacidad humana para recibir una comunicación divina y aprehenderla como tal. Rahner insiste en que esta proyección del hombre no es un algo añadido a su ser, sino que es «la condición misma de la posibilidad del conocimiento de lo creado y de la libertad de elección» ${ }^{2}$; o sea, algo aprióricamente constitutivo del fundamento del ser humano.

Para mostrar esta esencia del hombre en cuanto abierto a Dios, Rahner estudia lo que contiene su apertura: su conocimiento y libertad, su «espíritu», como ya está dicho. En los primeros libros de Rahner es el conocimiento humano el que ocupa su atención; luego aplicará esa misma técnica de estudio a la libertad ${ }^{3}$. En el presente trabajo sigo su análisis del conocimiento humano. De la libertad, que al fin y al cabo es algo uno con el conocimiento, se da juntamente con él en la realidad siendo su distinción más bien conceptual ${ }^{4}$, y por tanto, lo conseguido en el estudio del conocimiento valdrá, como principio, para la libertad, baste decir lo siguiente.

La libertad no es un poder del hombre para elegir una cosa u otra, sino más bien la facultad que tiene de disponer sobre sí mismo y de irse haciendo ${ }^{5}$, pues la libertad no termina en los objetos concretos sobre los que recae, como su fin, sino que se dirige al sujeto mismo que la realiza. Y esta libertad, aunque está necesariamente condicionada por una situación y unas determinadas circunstancias, ya que el hombre se encuentra siempre en el mundo, dentro de

2. García-Murga, J.R., Intimidad con Dios y servicio al prójimo; la tesis de GarcíaMurga no tiene en cuenta «Espíritu en el mundo» ni «Oyente de la palabra», de las que yo parto, sino obras posteriores. Pero su comienzo es válido aquí también, pues una de las características de Rahner es su continuidad en su concepción principal, con distinta insistencia en puntos derivados de ella.

3. «Lo que afirma santo Tomás del conocimiento - Dios es conocido implícita pero realmente en la aprehensión de todo objeto particular - vale también para la libertad» (RAHNER, K., Schriften zur Theologie, VI, 217. Citado por GARciA-Murga, op. cit., 38).

4. Sigo la distinción rahneriana de libertad originaria y libertad en cuanto encarnada en actos (RAHNER, Curso fundamental sobre la fe, 57). La libertad es siempre la libertad originaria, la capacidad humana de actuarse libremente, pero que al reflexionar sobre ella no se la puede captar más que en sus objetivaciones externas. La «libertad-manantial» se da inseparablemente unida al conocimiento, «en la libertad se trata siempre del hombre en cuanto tal y como un todo» (Ibid., $58)$.

5. RAHNER, Curso fundamental sobre la fe, 59. También Oyente de la palabra, 137. 
una realidad externa dada, es siempre, a pesar de todo, algo potencialmente imprevisible, no deducible de sus supuestos. Y esto es así por la trascendencia del hombre, por su ilimitada apertura hacia Dios, en la que supera los objetos concretos entre los que obra, que le condicionan ${ }^{6}$.

\section{La pregunta por el «ser»}

Veamos ahora el conocimiento, cómo muestra Rahner que en él se encuentra la apertura del hombre hacia Dios.

El comienzo de Rahner se basa en la inevitabilidad del hombre de preguntar. El hombre, en cuanto vive, pregunta, es pregunta; y pregunta por el «ser», es decir, por la realidad entera como unidad, y por sus últimos fundamentos, por el soporte originario del todo uno de la realidad 7 . Pregunta metafísica que todo hombre hace, pues la lleva en su mismo existir, se identifica con él.

El problema es ahora encontrar lo que Rahner llama el «desde dónde» de la pregunta ${ }^{8}$, su posibilidad de ser respondida, pues una pregunta que no puede ser contestada no es pregunta, desaparece como cuestión. Se trata, entonces, de buscar la respuesta a la pregunta metafísica, lo cual supone un problema especial, pues la pregunta por el ser es la pregunta por el todo, lo pone todo en cuestión, también la pregunta misma, ya que busca el principio de todo, lo primero. De este modo no hay un primer punto donde apoyarse, puesto que ese primer punto es por lo que se pregunta. ¿Por dónde se puede empezar si no hay referencia de partida?, ¿en qué terreno podemos situarnos con seguridad para iniciar el camino? La solución es empezar por la pregunta misma. No existe ninguna otra base que la pregunta que el hombre se hace necesariamente. Ahora bien, si la pregunta por el ser es la pregunta por la realidad como una, que el hombre lleva siempre en su vivir, entonces esa pregunta se refiere a su propia existencia, al hombre mismo, y al lugar en que se da esa existencia, el mundo. Es la pregunta por la realidad externa en la que el hombre se encuentra como existente. El hombre vive y, al mismo tiempo, de manera no refleja, ya pregunta por su existencia en el mundo que ve, o por la realidad del mundo en que se incluye su existencia.

Por lo tanto, la pregunta por el ser es la pregunta del hombre por sí mismo y por el mundo en que siempre está. Y si el punto de partida para contestar a la pregunta era la pregunta misma, entonces, este punto de partida es el hombre viviendo en el mundo.

6. RAHnER, Escritos de Teología, II, 256-257. Citado por GARCíA-Murga, op. cit., 36.

7. Éste es el punto de partida de la reflexión rahneriana tanto en «Espíritu en el mundo» (73ss) como en «Oyente de la palabra» ( $50 \mathrm{ss})$ es un claro paralelismo.

8. RAHNER, Espíritu en el mundo, 75. 
Partiendo, así, del hombre, hay que decir que su pregunta por el ser implica un cierto conocimiento de eso por lo que se pregunta. «No se puede en modo alguno preguntar por lo que no se conoce en absoluto y bajo ningún respecto» ${ }^{9}$. De manera que en el hombre, que inevitablemente se da una pregunta por el ser, se da, con la misma inevitabilidad, un cierto conocimiento del ser, una apertura hacia el fundamento radical de la entera realidad. El hombre se ve siempre implantado en el ser en general, viviendo dentro de una realidad ya dada, y por ello puede interrogarse sobre él y tener también una cierta idea de él ${ }^{10}$.

A su vez, la esencial pregunta del hombre supone un desconocimiento de lo preguntado, y lógicamente por eso se pregunta. De modo que se da en la existencia humana la paradoja de saber y no saber algo sobre el ser. Con todo, la conclusión primera a que se ha llegado es la apertura existencial del hombre hacia el ser, fuente primera del todo que el hombre experimenta.

De la misma manera, si el ser es una cuestión inseparable de la existencia del hombre que conlleva algún conocimiento de aquél por parte de éste, si el ser es algo conocido siempre por el hombre, en manera vaga, entonces el ser es por principio cognoscible. De modo que la cuestión metafísica, la pregunta general sobre el ser, establece la cognoscibilidad del ser. El ser está siempre, como principio, abierto al conocimiento del hombre ${ }^{11}$.

Resumiendo hasta aquí a Rahner. El hombre pregunta necesariamente, al mismo tiempo que vive, por el ser, su existencia es un preguntar por el todo de ella y su fundamento. Esto significa dos cosas, que en el fondo son la misma: De un lado, que el hombre conoce algo del ser, de otro modo ni siquiera podría preguntar, o sea, que el entendimiento del hombre está abierto al ser; de otro lado, y en el mismo modo, que el ser es siempre cognoscible al hombre, aunque no de forma evidente o clara, el ser está siempre abierto al hombre. Esto es lo que Rahner llama «la apertura del ser y del hombre» ${ }^{12}$.

Aquí habría que decir que Rahner matiza esta mutua apertura del hombre y del ser hablando, siguiendo a santo Tomás, de la unidad originaria entre

9. RAHNER, Oyente de la palabra, 56; también Espíritu en el mundo, 83.

10. Este argumento, de una lógica interna impecable, estará sin embargo en discusión respecto a su validez real. Porque mientras Rahner, y otros juntamente con él, deduce de una pregunta humana, real y vital, la del ser, un saber incierto sobre ello y, por tanto, la realidad misma de lo preguntado, otros, como ejemplo claro el Wittgenstein del «Tractatus», que parten de la misma realidad de la pregunta, concluyen que esa pregunta no tiene sentido, porque nada objetivo puede saberse sobre ese ser o fundamento del todo existente. Es decir, la existencia de una pregunta no conduce en modo evidente a que existe una respuesta y un cierto saber sobre aquélla.

11. Aquí hay que decir lo mismo que en la nota anterior, puesto que cognoscibilidad del ser parte del conocimiento oscuro que el hombre tiene de él siempre, dado el preguntar estructural del hombre sobre el ser.

12. Oyente de la palabra, 45 . Este es el título de la parte segunda del libro. 
el conocer y el ser, como consecuencia de la esencial cognoscibilidad del ser. En efecto, si el ser, y con él todo ente, es esencialmente cognoscible, esto sólo puede ser así porque ser y conocer están en una relación de unidad original, pues en caso contrario el ser de todo ente no sería «esencialmente» cognoscible. Una relación necesaria y esencial entre dos realidades lo es por su unidad intrínseca original. Si no estuvieran primigeniamente relacionados, esta relación sería accidental, no necesaria. Por lo tanto, el ser y el conocer están originalmente unidos, son la misma cosa. El ser es conocer, en unidad consigo mismo, conociéndose a sí mismo. El ser es conocer y ser conocido. De manera que todo ente, en cuanto tiene ser, es conocido por su unidad con el conocer, o sea que «algo es conocido en la medida en que se muestra ónticamente idéntico al cognoscente» ${ }^{13}$.

Pero, como ya se dijo, una pregunta supone, a la vez que un vago conocimiento de lo preguntado, que algo no se conoce, de modo que en un ente que pregunta por el ser, a la vez que una identidad entre el ente y el ser -pues la pregunta es conocimiento y el conocimiento es igual al ser-, debe darse una distinción entre ellos, porque si el ente es idéntico al ser no tendría que preguntar por él. Así pues, esta identidad del ente con el ser, la comprensión que el ente tiene del ser, sólo se puede aplicar de manera analógica con la «posesión del ser» que el ente tiene, en diferentes grados. Sólo en Dios se da la absoluta «posesión del ser», la identidad del ente con su ser.

\section{La «anticipación»}

Este primer paso dado por Rahner, mostrando en la estructura del hombre una irrenunciable pregunta por el ser y por tanto un oscuro saber sobre ese ser, que ahora ya veremos cómo lo podemos llamar Dios, lo confirma a continuación desarrollando un detallado análisis del funcionamiento de la razón humana, escudriñando el modo de conocer del hombre. Lo visto en el primer punto, la apertura del ser y del hombre, parece todavía un poco genérico para el tema que nos ocupa, la capacidad del hombre para entender una comunicación de Dios, y por ello este segundo punto intentará adentrarse en el mismo conocimiento humano y ver sus posibilidades de comprensión respecto a la incomprensibilidad divina.

Respecto a la relación ser y Dios. La palabra ser siempre ha sido un concepto desdibujado en la metafísica, lo cual no puede ser de otra manera si se tiene en cuenta la idea que encierra de principio y fundamento no visible de lo real. Esto se acentuó con Heidegger. Para Rahner, discípulo de Heidegger, el

13. Ibid., 61-57-69. Esta misma cuestión en modo más desarrollada se encuentra en Espíri. tu en el mundo, 79-92. 
ser sigue siendo el velado primero o último cimiento de todas las cosas, «el fundamento único de toda la realidad» ${ }^{14}$. Y en la pregunta incondicional del hombre «se anuncia el ser mismo por el que se pregunta y se esconde al mismo tiempo en su propia problematicidad» ${ }^{15}$. Esta idea de Rahner sobre el ser coincide con la noción cristiana de Dios, origen creador de todo nunca abarcable en su infinitud por la finitud humana. Por otra parte, si bien para Rahner Dios no es «el ser», es, con todo, el ente de la absoluta «posesión de ser», en el que el ente se iguala con el ser, y por tanto es un ente que es «puro ser» ${ }^{16}$, de manera que lo podemos identificar con el ser, si bien no debe ser una identificación matemática sino lógica.

El punto de partida es el hombre mismo, que ya vimos era el «desde dónde» de la cuestión metafísica existencial, tal como él se experimenta en su pensar y actuar. Se parte, pues, de lo empírico, lo evidente, para ir alcanzando conclusiones que procedan de una madura y coherente reflexión, que no se logran en un primer golpe de vista con la intuición.

El hombre se experimenta siempre en el mundo, rodeado de las cosas $u$ objetos que lo componen. Él, aunque forma parte del mundo, se sabe como alguien distinto de esos objetos y del mundo, se distancia de ellos por su pensar y obrar libre. Cuando piensa, cuando considera algo de lo que le circunda, se contrapone a eso, lo distingue de sí, lo hace «ob-jectum», es decir, puesto delante, según su etimología latina («jactum», arrojado y «ob», delante). Si el conocer algo es una identidad entre el cognoscente y lo conocido, como vimos anteriormente, pero también es una contraposición del que conoce respecto a su objeto, que pone frente a él, entonces tiene que haber un regreso del cognoscente a sí mismo en el que se destaque de lo que conoce. Es lo que santo Tomás conoce como «reditio completa subjecti in seipsum», en la que encuentra la peculiaridad de lo espiritual ${ }^{17}$. Y en este pensar del hombre sobre algo, que ha puesto frente a él, se emite un juicio sobre aquello que se tiene delante, es decir, se dice un predicado, un algo, del objeto en que recae la mirada. Y esto sucede siempre en el pensar del hombre sobre las cosas, atribuye algo a algo, se dice de un objeto que es así o de otra manera ${ }^{18}$. En otras palabras, todo pensar humano consiste en captar una cosa concreta, particular, bajo un concepto universal, aplicable a otros objetos particulares de la misma o distinta forma. El hombre entiende algo limitado (un ente, un objeto) desde un punto

14. Oyente de la palabra, 50.

15. Espíritu en el mundo, 74.

16. Oyente de la palabra, nota 1, p. $66 ;$ P. 69 y su nota 2 .

17. Espíritu en el mundo, 129-131; Oyente de la palabra, 75.

18. «En todo juicio se afirma un ente como tal, bajo una determinada peculiaridad: Esto es tal o cual» (Oyente de la palabra, , 77-78). 
de vista no limitado (un concepto, un atributo), permaneciendo en sí mismo en contraposición a lo conocido. Es lo que la metafísica tomista llama «abstractio».

Sobre la abstracción, según la metafísica del conocimiento en santo Tomás, Rahner ofrece un extenso apartado en «Espíritu en el mundo» ${ }^{19}$. A la primera recepción humana de lo otro, el mundo, que se conseguía mediante la sensibilidad, en una unión de dicha sensibilidad con lo recibido, con lo objetual, de modo que esa misma sensibilidad se indentificaba al objeto que captaba, corresponde la intelección humana, por la que se separa del objeto captado en la sensibilidad, volviendo a sí mismo y haciendo a lo otro un objeto ante el que él está como sujeto consciente, lo cual es la característica más propia del pensar humano. Se dan, pues, dos momentos en el conocer humano, uno de entrega al mundo, por la sensibilidad, en el que se confunde con el mundo, y otro de regreso a sí mismo, «reditio completa», por la abstracción, en la que el hombre, en sí mismo, conscientemente, se enfrenta, juzga los objetos del mundo. Dos momentos sólo conceptuales, no reales separadamente, que conforman el único conocer humano.

La abstracción, retorno del pensante a sí mismo y juicio sobre los objetos a que se opone, comporta siempre un concepto universal. Concepto universal significa que se da en muchos, que puede ser dicho de muchos. Un objeto concreto sobre el que se piensa lleva siempre un universal: «esto es de esta clase ${ }^{20}$. Y el concepto universal se capta en cuanto referido a algo concreto: «la clase de esto», o si se le considera en sí mismo, se le reduce a actuar como algo concreto, del que se dirá un algo universal; esto último es otro término tomista empleado abundantemente por Rahner: la «conversio ad phantasma». Todo pensar, una de cuyas partes conceptuales era la abstracción, consiste en esto, algo universal afirmado de algo particular. La abstracción, por ello, lleva siempre un contenido universal, que el hombre aplica a (o sustrae de) un objeto y así, al tiempo, se distingue de él ${ }^{21}$.

El siguiente paso es ver el por qué de la abstracción, por qué el pensar humano es atribuir algo no limitado a un objeto limitado. Por qué el hombre re-

19. Espíritu en el mundo, 129-234, que es el capítulo III de la segunda parte.

20. Ibid., 133. Sigo los mismos términos que utiliza Rahner porque me parecen muy clarificadores.

21. «La esencia del conocimiento humano viene circunscrita por la unidad de estos dos momentos: el intelecto se encuentra cabe sí mismo como él mismo, porque en el referir de lo universal sabido a algo y en el juicio sobre algo se destaca frente a esto algo. Pero sólo 'en' este destacarse frente a lo otro se encuentra el intelecto 'cabe sí mismo', y sólo así es permanentemente consciente de sí mismo» (Ibid., 143). Esta capacidad de aplicar algo universal a algo singular y conseguir con ello la propia consciencia en contraposición a lo conocido, pertenece según Rahner al concepto tomista de «intellectus agens» (Ibid., 144). 
conoce aquello sobre lo que piensa como limitado, como concreto, del que dice algo que también se puede concretar, percibir, en otros objetos limitados.

Si al pensar, al abstraer, que en latín significa alejar, arrancar, separar, se separa algo ilimitado, porque puede ser aplicado a muchos objetos $-\mathrm{y}$ por tanto es un universal-, de un objeto limitado, porque en él se da de manera concreta ese algo ilimitado dicho, hay que concluir que el hombre al pensar ya tiene en la cabeza esa idea universal, pues de otro modo no la podría aplicar o separar del objeto sensible que examina, del cual se parte. Más todavía, este universal es la condición de posibilidad del pensar humano. Sin él no se daría ese proceso característico que hemos visto en la abstracción. Y como la consciencia, la capacidad de pensar sabiendo que se piensa, es la cualidad primordial de todo ser humano, esto quiere decir que la estructura del hombre lleva en sí ese concepto universal, que le capacita para pensar, para ser un hombre en el pleno sentido de la palabra.

De otro lado, el objeto particular lo conoce el hombre como limitado reflexivamente, porque puede percibir en él de forma concreta, delimitable, el universal que tiene ya en su mente. El poder decir, al pensar, de una cosa «esto es de esta clase», supone que esa «clase» de perfiles inciertos en sí misma se ve representada en modo concreto en un «esto» objetual, que está dentro, como otros muchos objetos, de un atributo ilimitado.

De la misma manera, hay que decir que la ilimitación, el universal, sólo será reflejo una vez aprehendido el objeto externo como formando parte de una cualidad no concreta. Nos damos cuenta de nuestro universal constitutivo cuando lo atribuimos a un particular sensible.

Así pues, este universal es la condición trascendental, apriórica, necesaria para que se dé el conocer humano, su facultad abstractiva. A esta tendencia hacia el universal que forma parte en modo apriórico del hombre, que le posibilita como ser pensante, Rahner denomina «anticipación», término que si bien no se halla expresamente en santo Tomás, corresponde a la idea tomista que está detrás de la palabra «excessus» ${ }^{22}$. Rahner define así la anticipación: «Es una facultad — dada a priori con la esencia humana-de moverse dinámicamente el espíritu hacia el ámbito absoluto de todos los objetos posibles, con un movimiento en el que los objetos particulares son en cierto modo aprehendidos como momentos particulares en ese moverse hacia un fin y así son captados en forma cognoscitiva en esa mirada previa dirigida hacia el ámbito absoluto de lo cognoscible»» ${ }^{23}$.

El objeto de la anticipación, la meta a la que tiende, no es algo represen-

22. Ibid., 152.

23. Oyente de la palabra, 81 . 
table, como un objeto sensible. Porque si el conocimiento de un objeto se funda en la anticipación, ésta misma no puede ser un objeto y ser conocida por otra anticipación. Pero si queremos estudiar este fin de la anticipación, esto sólo será posible si lo reducimos, en una «conversio ad phantasma», a ser un objeto, aunque no lo sea de hecho. De modo que para examinar la anticipación tenemos que partir de ella misma, que se nos hace consciente en el acto de conocer un objeto concreto, como algo que supera, y por lo mismo limita, dicho objeto concreto ${ }^{24}$.

Se quiere ver el horizonte de la anticipación, el «sobre qué» -en palabras de Rahner - al que se dirige; ver su amplitud, el relativismo o absolutez de su ilimitación.

El conocer humano, cuya condición trascendental es la anticipación, recae, al menos en principio en el ente, en su «en sí». Por ello el conocimiento de un objeto sensible deberá ser interpretado como consecuencia de una anticipación tendente al «sí», o sea, al ser más que a la nada ${ }^{25}$. El universal que sustenta la anticipación, ilimitación que se percibe limitada en un objeto que se conoce, desechará una trascendencia hacia la nada. Ciertamente la anticipación lleva consigo una ilimitación negativa ${ }^{26}$, pues esa ilimitación se determina como negación del límite que aparece en una cosa particular, objeto del conocimiento. Pero es la anticipación en cuanto encaminada a lo ilimitado como base del conocimiento, la que niega lo finito; no es la negación la que hace posible la anticipación ${ }^{27}$.

De este modo el problema del «sobre qué» de la anticipación se ceñirá a si apunta a una ilimitación relativa o, por el contrario, absoluta. Según Rahner la hipótesis primera es contradictoria. Y esto porque si la anticipación, que supera la finitud intrínseca de todos los objetos del conocer humano y hace que esa finitud sea sabida, no tiende a la infinitud del ser, tenderá entonces, inevitablemente, a la nada. La infinitud de la anticipación si tiene un límite, es que se proyecta hacia la nada, es decir, no es infinita, se contradice a sí misma ${ }^{28}$.

La anticipación, por tanto, se refiere a la infinitud absoluta del ser, al ser

24. Espiritu en el mundo, 152-154.

25. Oyente de la palabra, 84. Ahí mismo lo que sigue.

26. Espíritu en el mundo, 188.

27. Rahner dice esto inmejorablemente: «No es que la nada sea anterior a la negación, sino que la 'anticipación' que apunta a lo ilimitado es ya en sí misma la negación de lo finito, porque -y en cuanto que - dicha 'anticipación', como condición de posibilidad del conocimiento de lo finito, al superarlo y trascenderlo, 'eo ipso' pone de manifiesto su finitud. Por tanto, el sí que se da a lo de suyo ilimitado posibilita la negación, y no al revés (...). La ilimitación positiva del horizonte trascendental del conocimiento humano, muestra ya por sí misma la finitud de todo lo que no cubre completamente este horizonte» (Oyente a'e la palabra, 84).

28. Ibid., 85 . 
en sí ilimitado. Lo que es tanto como decir que la anticipación se refiere, tiene su «sobre qué», en Dios, el ente de la absoluta «posesión de ser», el ente que posee, que es, el ser absoluto, el «puro ser». La anticipación, condición trascendental de todo ser humano como humano, de su conocer y obrar, afirma, aunque no la representa, pues ya ha sido dicho que el horizonte de la anticipación no era un objeto delimitable, la existencia de Dios. La anticipación se dirige hacia Dios, afirma su ser, no en su identidad sino en su amplitud.

De esta conclusión de la existencia de Dios Rahner dice que no tiene nada que ver con una argumentación apriórica. Porque se ha llegado a la existencia de Dios desde la anticipación, y ésta ha sido captada a partir de los entes reales, como presupuesto de su conocimiento, y, por consiguiente, de forma aposteriórica. Del ente finito se llega, como condición necesaria para la aprehensión de tal finitud, al ente infinito. Rahner coloca su argumentación en el orden de lo real-ontológico, que es el empleado por santo Tomás en sus pruebas de la existencia de Dios ${ }^{29}$.

Llegados a este punto podemos decir que todo conocimiento humano lleva implícito el conocimiento de Dios. En efecto; si todo conocimiento del hombre consiste en una atribución universal que se afirma de un objeto singular, por la apriórica anticipación que forma parte del ser humano, y que es condición de posibilidad de su conocer, y si la anticipación tiende por sí misma hacia la ilimitada capacidad del ser, hacia Dios, quiere esto decir que todo conocimiento humano es posible en cuanto que tiende intrínsecamente a Dios, en cuanto su punto de mira está originalmente en Dios.

Con esto Rahner ha dado un paso muy importante. Ha conseguido mostrar que en la estructura esencial del hombre, en su razón, hay algo universal, ilimitado, una apertura al infinito absoluto, a Dios mismo. Y esto es parte imprescindible del ser humano, le permite su conocer y obrar, es decir, no puede no darse. A esta realidad del hombre la llama Rahner «espíritu» ${ }^{30}$. Y, según ella, el hombre es capaz de oír, y entender como tal, la revelación de Dios, la comunicación divina en cuanto infinita automanifestación, sin disminuirla o cercenarla, porque él mismo, hombre, es siempre una apertura al infinito.

Así pues, en resumen, en este primer capítulo se ha visto que Rahner considera al hombre un preguntar viviente, el hombre es una pregunta constante, y una pregunta por el todo de la realidad y por el fundamento último que la sostiene. El hombre está abierto, en cuanto que existe, al ser, a la realidad que cimenta las cosas. Prosiguiendo el camino empezado, entrando más en detalle en lo específico del hombre, Rahner advierte que la razón humana es, en últi-

29. Espíritu en el mundo, 186; Oyente de la palabra, 87.

30. Espiritu en el mundo, 190; Oyente de la palabra, 89. 
mo análisis, una facultad que abarca el infinito, que es capaz de contener la amplitud de Dios - sin ninguna representación-, o sea, que el hombre puede sentir y reconocer una revelación de Dios por la ilimitación de su «espíritu».

Con esto ha dejado clara una de las premisas de toda teología de la revelación: la capacidad del hombre de escucharla. Premisa más o menos descuidada anteriormente.

Quizá el estudio del conocimiento humano de santo Tomás, que sigue Rahner, no sea asumible hoy día en sus detalles y divisiones, pero sí en lo básico: el conocimiento del hombre de las cosas es posible por la mayor amplitud de aquel, que le permite incluir una cosa, al conocerla, en una categoría más ancha que ya posee («esto es de esta clase»), contradistinguiéndose de ella como sujeto. Conocer es comprender, es decir, abarcar una cosa, circunscribirla, precisamente porque se la supera. Y el conocer supone algo ilimitado, que es lo que hace ver algo como limitado, que no es en forma total lo que se le atribuye.

La ilimitación de la razón humana para el conocimiento quiere decir que sus límites son imprecisos, no pueden delinearse. Rahner pasa de aquí a la ilimitación absoluta, pues una ilimitación limitada es contradictoria en sus términos, y de ahí la identifica con Dios, todo lo cual es un razonamiento lógico. Pero Rahner ya supone el ser de Dios por la fe; Dios no se puede probar, es un acto de fe-confianza del hombre. Rahner muestra que la decisión fiducial del hombre respecto a Dios tiene sus fundamentos racionales, y fuertes, no es absurda. El paso de la ilimitación de la fuente del pensar humano a su ilimitación absoluta es coherente y convincente. No es evidente en modo matemático, sin duda, pues de un razonamiento lógico no se puede deducir irrefutablemente su realidad, pero tiene validez. La misma coherencia, aunque también la misma falta de evidencia incontestable, lleva a considerar a la infinitud total a que tiende el hombre como Dios, ser personal perfecto, meta del ser personal del hombre en su devenir.

Dentro de esta solidez discursiva de Rahner se enmarca con firmeza lo alcanzado en este primer capítulo: el hombre, por su razón y su obrar libre, es un ser abierto a la inmensidad, su mente descansa en la inconmensurabilidad de Dios. Puede, por tanto, acogerla en una revelación, es «espíritu».

\section{EL HOMBRE COMO «MUNDO»}

La conclusión reciente de Rahner de la natural apertura humana hacia la infinitud divina, de valor imprescindible para comenzar una teología de la revelación, podría, a primera vista, parecer contraproducente y oponerse al núcleo mismo de toda comprensión teológica de la revelación. En efecto. Tras la 
afirmación central del capítulo anterior sobre la apertura del hombre y del ser, se llegaría a una grave aporía. De una parte el hombre, por la ilimitada amplitud de su espíritu, estaría capacitado para desentrañar los últimos secretos de Dios. Dios no sería alguien que puede revelarse al hombre porque éste lo abarcaría totalmente por sí mismo. De otra parte el ser, y Dios como ser absoluto, confirmaría esta imposibilidad de revelación: si el ser es necesariamente cognoscible y luminoso, Dios, absoluta posesión de ser, sería la luminosidad por excelencia, brillo que inundaría todo lo real, evidente para la trascendentalidad absoluta del hombre. No habría sitio, pues, para una revelación, comunicación divina que hace al hombre participar de su misterio y amor inexhauribles ${ }^{31}$.

Se trata, por tanto, en este segundo capítulo, de ver cómo Rahner puede compaginar la irrenunciable realidad de la tendencia del hombre hacia Dios -y la esencial luminosidad del ser- con la creencia cristiana, y por lo demás intuición universal del hombre religioso, de Dios como misterio absoluto e inalcanzable para la mente humana. De manera que Dios siempre «podría» comunicar algo al hombre y, con todo, permanecería siempre misterio, cualidad fundamental de la divinidad. Hay, pues, que mantener la esencial apertura hacia el absoluto del espíritu humano a la vez que la esencial misteriosidad u ocultamiento de Dios.

\section{Finitud del hombre}

Un primer punto de acercamiento a la respuesta se ha dado ya en la anterior reflexión rahneriana. El hecho de que el hombre sea existencialmente un preguntar indicaba su finitud. El hecho de que para el hombre sea sinónimo vivir y preguntar, que no puede evitar hacerse interrogaciones lo mismo que no puede evitar el existir en un momento dado, expresa la limitación de la realidad humana. Que el hombre pregunta significa que hay algo que no sabe, que algo le supera, aunque signifique también que el hombre tiene una cierta idea de lo preguntado. Además, la capacidad infinita de la inteligencia humana, la «anticipación», no representa un algo infinito en su identidad sino que sólo lo afirma como infinito.

También, esta anticipación no se da en el hombre en sí misma, sino dependiendo de algo finito. Es decir, la anticipación del hombre sólo es actuada en el momento en que el hombre conoce una cosa concreta. Ciertamente la anticipación es un a priori humano, dado con el mismo hombre, que le cualifica como ser pensante, le capacita para atribuir algo universal a algo particular

31. Oyente de la palabra, 95-98. 
por la previa noción de lo universal que le da dicha anticipación; pero esta anticipación es algo abstracto que en la práctica no existe por sí, sino que siempre existe en cuanto posibilita el conocimiento de las cosas; es decir, siempre existe en cuanto que parte de un objeto limitado, que juzga limitado por su cualidad previa ilimitada que le hace ver el objeto como un momento acabado de la infinitud que el hombre ya posee.

Más sencillamente. El hombre conoce las cosas, las juzga, dice de ellas algo universal, que éstas tienen sólo limitadamente: «esto es de esta clase». Y en un segundo momento se da cuenta, al reflexionar sobre su modo de conocer, que ese proceso es posible porque él ya tiene antes una infinitud, que le permite juzgar lo que se ofrece a sus ojos como finito. De modo que el hombre sólo sabe de su anticipación a partir de los entes finitos. La infinitud de su anticipación sólo le es perceptible a partir de lo finito o, en palabras distintas, la anticipación no se da en manera pura, aislada, sino siempre unida con las cosas concretas, materiales, en una palabra, con el «mundo» ${ }^{32}$.

Lo mismo desde otro punto de vista ${ }^{33}$. El conocer humano es, en principio, receptivo, es sensibilidad, es decir, consiste primariamente en intuición. Pero es también ser en sí mismo, retornando a sí desde la materialidad de la sensibilidad, comprendiéndose como distinto y comprendiendo también lo material en su limitación. Para que se realice esta peculiaridad del conocer de volver el hombre sobre sí mismo tras su coincidencia intuitiva con la materia, y circunscriba a ésta en unos límites, es preciso que el hombre se entienda como poseedor de una capacidad que sabe ver las cosas como incluidas en un concepto más amplio que forma parte de su inteligencia. Ésta es la llamada abstracción, que será más importante que la sensibilidad, ya que es aquélla quien hace brotar a ésta como primer paso del conocimiento humano ${ }^{34}$. Pero la abstracción, para ser tal, necesita comenzar desde la sensibilidad. La abstracción, como se acaba de decir, depende de ese primer paso que es la sensibilidad para consumarse. Y ésta es la «conversio ad phantasma». La abstracción no puede resultar más que convirtiéndose a lo material y cerrado, la idea universal sólo la podemos entender imaginándola particular, en una «conversio ad phantasma». Los «phantasmata», conceptos, tienen el valor de hacernos intuir lo universal ${ }^{35}$. Pues si primero tenemos lo universal, que nos hace conocer lo particular, sólo conociendo lo particular mediante la aplicación de

32. «Mundo» no es sólo lo sensible inmediato, dice Rahner. Es más bien, todo lo que el hombre puede experimentar en su vida (Oyente de la palabra, 187, 206; Espíritu en el mundo, 386).

33. Siguiendo el estilo de «Espíritu en el mundo» que divide su central parte II en tres apartados: sensibilidad, abstracción y conversio ad phantasma.

34. Espíritu en el mundo, 258, 276.

35. Ibid., 265. 
nuestro universal, phantasma o concepto, llegamos a ser conscientes de dicho universal previo.

La abstracción se realiza al darse una «conversio» de la estructura apriórica del espíritu sobre la sensibilidad. «Toda abstractio, es decir, todo conocimiento de lo universal, es esencialmente conversio ad phantasma» ${ }^{36}$, con lo que llegamos a una unificación de la realidad de las dos cosas. La posibilidad del pensamiento humano se asienta en una relación de unidad entre materia y espíritu o sensibilidad y abstracción.

La consecuencia de esto es que el hombre no puede reflexionar directamente sobre sus conceptos universales, sino que los debe mediatizar siempre con lo concreto. La aproximación intelectiva humana a su universal se cumple únicamente mediante una conversio ad phantasma, dando al universal una estructura concreta, para luego, en un intento de mayor acercamiento, negar esa estructura concreta o, mejor dicho, ver negativamente esa estructura concreta como representación del universal.

Aplicando esto a Dios habrá que decir que su ser trascendente y absoluto sólo puede ser conocido desde lo inmanente y mundano. La infinitud de Dios será captada mediante lo que Rahner llama «experiencia trascendental del límite» ${ }^{37}$, que niega la finitud de la que se parte para acercarse a una comprensión de la divinidad o para alejarse de una reducción a lo finito de la divinidad. Teniendo en cuenta que el ser de Dios sólo es accesible a través de una negación, negación de la finitud de la que hay que partir, y no en modo directo, y que la anticipación muestra la amplitud indeterminada de Dios, pero no la representa, la conclusión es que el hombre en modo alguno puede entender totalmente a Dios. La revelación tiene entonces razón de ser.

Dios, entonces, es el Desconocido para el hombre ${ }^{38}$, al que éste sólo llega oscuramente a partir de la negación del límite de las cosas que puede conocer. Pero parece que ello se debería sólo a la limitación del hombre, que por otra parte podría ser temporal y superable.

La finitud del hombre es vista por Rahner como necesaria. Se parte de nuevo de la cuestión primera de la metafísica: la pregunta por el ser que se da en todo hombre, en su segundo aspecto, la problematicidad que el ser supone para el hombre, el desconocimiento que el hombre experimenta en lo que concierne al ser, y que motiva que se pregunte por él. El hombre pregunta necesariamente por el ser y con ello afirma que necesariamente sabe algo del ser, ya que pregunta por él, y que el ser es necesariamente cognoscible; pero, a la vez,

36. Ibid., 271. Rahner examina esta conversio ad phantasma todavía desde muchos ángulos. Pero lo que fundamentalmente interesaba aquí sería lo dicho.

37. Oyente de la palabra, 102.

38. Ibid., 107. 
afirma que necesariamente hay algo que no sabe del ser puesto que pregunta por él en modo necesario. En la cuestión existencial del hombre se ven afirmadas la preguntabilidad y luminosidad del ser ${ }^{39}$. El conocimiento que el hombre tiene del ser no es una identidad del hombre con el ser porque el ser permanece oscuro para el hombre, dado que se interroga constantemente sobre él. El conocimiento que el hombre tiene del ser es analógico, según su «posesión del ser» ${ }^{40}$. El hombre, entonces, es finito porque no abarca el ser que se presenta ante él. Y si necesariamente pregunta por el ser es que es finito necesariamente.

En la realización del hombre como hombre, en su pensar y obrar libre, el hombre tiene obligatoriamente que estar consigo. El pensar, que constituye al hombre como tal, consiste en separarse el hombre de las cosas sobre las que piensa, de autoafirmarse en sí como diferente. $\mathrm{Y}$ en ese distinguirse y experimentarse como único, el hombre pregunta por sí y por el lugar donde se ve. El pensar, la característica del hombre, es primeramente el preguntar. El hombre, en cuanto hombre, pregunta y muestra ahí su contingencia inevitable ${ }^{41}$.

Resumiendo lo dicho hasta aquí sobre la finitud del hombre para verlo de forma global. El hombre no puede aprehender el ser de Dios y no hace inútil una revelación. Esto se trasluce de la realidad vital del hombre que pregunta necesariamente por el ser, lo cual quiere decir que no lo conoce. Por otra parte, la capacidad infinita del intelecto humano es tal a partir de las cosas finitas, de modo que la inteligencia de lo infinito sólo se forma con la negación de lo finito de que se parte, $y$, por tanto, no directamente. Y por último, la anticipación, esa tendencia hacia el infinito absoluto de Dios característica del ser humano como racional, no aporta imágenes o representaciones de la meta a la que se dirige, sino sólo vagos perfiles.

Todo esto muestra, paradójicamente, la finitud de la infinitud espiritual humana. El conocimiento del infinito en el hombre no se da de modo inmediato, evidente, sino siempre mediante su ser en el mundo - por el que necesariamente pregunta-, mediante las cosas concretas, que son el punto de partida

39. Ibid., 111.

40. Véase p. 3 de este trabajo.

41. Quizá por repetir excesivamente la finitud necesaria del hombre al querer presentarlo en modo racional, se llegue a oscurecer la misma experiencia del hombre de su contingencia. Rahner, de todas maneras, con un lenguaje fuertemente paradójico, logra expresar esta experiencia de la finitud humana: «Por cuanto debe (necesariamente) preguntar, afirma su propia contingencia; por cuanto debe (preguntar) necesariamente, afirma necesariamente ésta su contingencia. Y al afirmarla necesariamente, afirma su existencia, y la afirma -en su contingencia y a pesar de ella - como incondicional, como absoluta. Con otras palabras: Dado que la afirmación del hecho contingente es ineludiblemente necesaria, en la contingencia misma se descubre algo absoluto: La ineludibilidad con que el hecho contingente reclama de por sí su afirmación» (Oyente de la palabra, 113). 
hacia la totalidad, a través de la negación de ellas, y por tanto su información no es perfecta. El hombre es «espíritu», pero siempre en el «mundo».

No obstante, se está considerando sólo el ser del hombre, como si de él únicamente dependiese su desconocimiento de Dios y como si, entonces, en el futuro, en un momento posterior y más desarrollado de su evolución, pudiese superar esa situación ${ }^{42}$. No se ha hablado desde el mismo ser de Dios, que así sigue siendo la luminosidad absoluta, disponible abiertamente al hombre. El tema siguiente deberá ser éste. Ver si Dios no sólo es cognoscible sino también, y más radicalmente, misterio inescrutable ante el que solamente cabe la adoración ${ }^{43} \mathrm{y}$ la esperanza de que nos dirija su palabra.

\section{Ocultamiento de Dios}

Éste podría haber sido el título del presente capítulo, dado que el ser de Dios expresa mejor la imposibilidad de conocerle que la limitación del hombre.

a) El misterio del ser divino.

Rahner advierte que en la concepción del misterio de la teología fundamental última que nos ha llegado, se desgajaba el misterio único de Dios en los varios misterios de que nos hacía partícipes por la revelación. Los enunciados de la revelación eran verdaderos, pues provenían de Dios, pero eran oscuros en sí, eran misterios no descifrables por la razón y por ello eran objeto de fe. No eran iguales a los misterios profanos, del mundo, que progresivamente iban siendo desvelados por la razón humana. Los misterios religiosos, conocidos para el hombre por la revelación, superaban su razón y se mantendrían incompresibles durante la vida terrena del hombre. Lo cual quería decir que en la otra vida podrían por fin ser entendidos ${ }^{44}$. La constitución de los misterios religiosos era vista a la luz de los misterios mundanos, que participaban de la finitud terrestre y eran dominados por la razón del hombre, que era superior a la naturaleza, insaciable en su buscar luces y a la que no detenían en su afán ni siquiera las cosas trascendentes. La analogía hizo considerar que los misterios religiosos, una vez que el hombre tomara contacto directo con ellos al formar también él parte de la vida de la trascendencia, serían sin duda clarificados satisfaciendo la fuerza de la inteligencia humana ya manifestada en la tierra. El ser misterio dependía, así, de la razón humana: donde ésta no llegaba ahí se tenía el misterio. Los misterios de Dios eran provisionales, no lo eran en sí, de-

42. Ibid., 102 .

43. Ibid., 108; idea de Heidegger citada por Alfaro en su curso 1981-82 sobre «la cuestión del hombre y la cuestión de Dios».

44. RAHNER, Escritos de Teología, IV, 56, 58. 
pendientes de la distancia infranqueable que les separaba del hombre peregrinante.

Rahner dice que el misterio religioso no debe ser considerado desde lo que la razón no puede desentrañar. La razón humana, por ser la tensión hacia la trascendencia absoluta, es más bien lo que presencializa el misterio como tal, no lo que puede anularlo. El conocer humano es la facultad del misterio porque el conocer se basa en sobrepasar el objeto que se aprehende y anticipar lo absoluto, lo inabarcable. Y el misterio religioso no será algo transitorio sino lo permanente y primigenio. Dios es sobre todo el incomprensible, incluso en la visión beatífica, que no consiste en el desvelamiento de Dios sino en la manifestación de su misterio absoluto. Será ver directamente la incomprensibilidad de Dios, afirmar a Dios como misterio radical en nuestra evidencia dichosa. Nuestro mayor conocimiento de Dios será la cercanía total a su misterio insondable ${ }^{45}$.

Dios es el único misterio. Los misterios de la revelación de que se habló en teología provenían todos del ser divino, de modo que los misterios en plural dependían y brotaban del misterio absoluto y único. La concepción auténtica del misterio será vista a la luz de la relación de Dios con el hombre, pues el hombre puede dominar los misterios finitos de la realidad material, y Dios para sí mismo no es misterio, es el perfecto ser en sí y por consiguiente totalmente luminoso (su luminosidad, empero, para el hombre es la luminosidad de su ser como misterio). Y si el hombre, como se ha repetido, es el ser espiritual que se dirige a Dios en su pensar y obrar, en su esencia, el hombre entonces va por su propia constitución hacia el misterio, anticipándolo en cada acto humano característico. El hombre, de este modo, es el ser del misterio, que se desarrolla en su vida en su tendencia a la infinitud misteriosa, y cuya plenitud será la contemplación inmediata del misterio, la llegada a la meta con el reposo de la visión del misterio supremo.

Otro modo de acercarse a la comprensión del ser absolutamente incomprensible como tal que es Dios, es el de ver su libertad. La libertad hace al hombre un ser indeducible, al menos como última posibilidad. Los condicionamientos insalvables que le impone el mundo no merman, antes bien hacen posible, la última y decisiva imprevisibilidad de su libertad. La libertad hace del hombre, en su consciencia, un ser inaccesible. Pero si la libertad del hombre, que es el mismo hombre, por su finitud o dependencia de lo finito, puede ser parcialmente controlada, la libertad absoluta que es el Dios absoluto mostrará la total, e incluso espantosa radicalidad del misterio divino.

b) la libertad de Dios.

Para seguir adelante con el tema del ocultamiento de Dios tenemos que

45. Ibid., 60 . 
volver a la concepción del hombre como contingencia necesaria. El hombre existente, que pregunta por su vida al tiempo que vive, se experimenta como puesto en el mundo independientemente de su voluntad. Existe contingentemente, por algo fuera de él. En esta existencia el hombre se interroga sobre el ser y por tanto conoce al ser, y por lo mismo el ser es cognoscible, luminoso; se interroga y sabe del ser como fundamento de su existencia y de la realidad en que está. Si el ser es necesariamente luminoso, porque necesariamente se pregunta y se sabe de él, el șer debe ser libre. Porque si el hombre no es necesario sino contingente, es decir, que podría no haber sido, alguien habrá decidido ponerlo, y por eso ese alguien es libre ${ }^{46}$. Ahora bien, si Dios es el ser absoluto, fundamento de todo lo que es, Dios es ese «alguien» libre que ha puesto al hombre.

Así que el hombre se afirma necesariamente como contingente, puesto voluntariamente por Dios; se sabe mantenido por el poder libre de Dios. Y entonces el hombre se encuentra ante Dios como ante una «persona» libre, dueña de sí ${ }^{47}$. Todo esto nos lleva a dos consecuencias: De un lado el hombre no puede predeterminar en absoluto el ser y obrar del Dios absolutamente libre. Y de otro, el hombre frente al Dios libre es un hombre frente a un Dios que puede actuar libremente hacia él, con una consiguiente automanifestación. «La trascendencia del hombre hacia el ser absolutamente luminoso en sí, de cognoscibilidad inexhausta, es al mismo tiempo por lo menos la apertura ante un Dios de libre acción con el hombre, acción que por parte del hombre no se puede calcular, por lo cual la trascendencia hacia el ser absoluto de Dios equivale a hallarse ante el 'mysterium imperscrutabile', cuyos caminos son inescudriñables y cuyos designios no se pueden rastrear» ${ }^{48}$. Lo cual es sencillamente decir que existe una posibilidad de revelación por parte de Dios, de la que el hombre por sí mismo no puede disponer sino sólo esperar como un don.

En este contexto el hombre es alguien que tiene que estar preparado para una posible revelación de Dios. Su existencia es la actitud atenta a una manifestación que Dios le pueda conceder, y que, según Rahner, siempre se produce, pues si Dios no habla podrá de todos modos escucharse su silencio. El ser espíritu del hombre le hace perceptible el silencio o palabra divinos, le convierte en un oyente permanente de la revelación de Dios. El obrar libre de Dios es el sentido metafísico de la revelación, que por tanto siempre se realiza y conlleva una manifestación de su propia esencia. En este sentido la revelación es

46. Oyente de la palabra, 114-115. Fatigosa explicación de Rahner sobre la libertad del fundamento del hombre. Podría simplificarse basándola en la misma libertad del hombre. De todas formas, lo que Rahner niega ha sido afirmado también en la filosofía, por ejemplo existencialista: el hombre contingente y libre está puesto por azar.

47. Ibid., 116 .

48. Ibid., 119-120. 
necesaria y en base a ello el hombre puede esperar una revelación explícita, en sentido teológico, en la que Dios, libremente, dirija su palabra al hombre ${ }^{49}$.

Así pues, el ser libre de Dios muestra una vez más la validez de la revelación, que la anticipación humana no hace superflua. El segundo punto de este apartado va a referirse a la libertad del hombre frente a la libertad de Dios para con él, es decir, frente a una manifestación de Dios.

Repitamos que el hombre, como necesariamente contingente, no puede evitar preguntar por el ser y encararse a Dios; afirmando con ello la luminosidad y, a la vez, la libertad y por tanto oscuridad o imprevisibilidad del ser absoluto. Pero esto es en relación con el hombre. ¿Cómo entender eso mismo desde Dios? ¿Es Dios luminoso para sí mismo o es, por ser libre, oscuro? Si lo contingente se comprende no desde sí mismo sino desde su fundamento $-\mathrm{y}$ por ello todos los entes finitos del mundo son captados dentro de su movimiento hacia el ser en general porque éste es el que los fundamenta- ¿Puede Dios entender sus acciones libres, dado que su libertad no tiene ningún fundamento? ${ }^{50}$. ¿La libertad y la luminosidad de Dios se oponen?

La respuesta tendrá que partir de la misma pregunta, pues no tiene ninguna otra base. Luminosidad es el estar consigo del ente en su ser. Y este estar consigo del ente en su ser es también conocimiento. Ser y conocer están en unidad esencial ${ }^{51}$. De este modo el ente que está perfectamente consigo tendrá la perfección del conocer. Por su parte la acción libre no es sobre todo hacer algo, poner o sacar algo desde uno mismo y dejarlo fuera de sí, pues la libertad no se dirige como fin a una cosa externa sino que va hacia sí misma en orden a su realización. Libertad es actuar hacia uno mismo, ir a uno mismo, a un estar consigo. Por consiguiente libertad es lo mismo que conocimiento: estar consigo un ente en su ser. Libertad no es otra cosa más que uno mismo y por ello es luminosa, comprensible para el que actúa, mientras será oscura para otro, pues éste no tiene acceso a la libertad ajena como capacidad, como manantial del que brotan los actos, sino sólo a estos actos, y éstos son ambiguos, no siempre reflejan exactamente la intención de la libertad originaria ${ }^{52}$.

Aquí es imposible resistir citar textualmente a Rahner: «El hecho de que la acción libre forme parte del sentido más íntimo del ser que está en sí mismo, muestra al mismo tiempo que es íntimamente luminosa para el yo libre, pero

49. Ibid., 120-121.

50. «La posición libre (contradistinta de lo puesto), ¿no es a su vez algo incomprensible, ya que lo libre en cuanto tal no tiene ningún fundamento del que como tal proceda necesariamente y en esta forma pueda comprenderse e iluminarse? Con otras palabras: ¿Comprende el mismo Dios libre su acción libre? ¿O también para él mismo queda incomprendida en su 'contingencia' y 'falta de fundamento'?» (Ibid., 128).

51. Cfr. p. 9 y nota 13 de este trabajo.

52. Oyente de la palabra, 129; Curso fundamental sobre la fe, 57, 59. 
oscura para otro distinto de él: tal acción es lo que más está en sí mismo, por lo cual es lo más luminoso en sí mismo y para sí mismo y lo menos transmisible a otro: en sí mismo es luminosa y para otro es oscura. Sólo puede hacerse clara y comprensible para otro si este mismo la correaliza con una acción libre, si él mismo la ama» ${ }^{53}$. Es decir, que la libertad, por su hondura en el centro más íntimo de cada uno, a la vez que es clara para el actuante no lo es para el que la observa, en su concreción en acciones, desde fuera. Si quiere entenderla debe incluirse en esa acción, debe él también realizarla, para no quedarse sólo en lo puesto, en la acción externa, sino que, al realizarla, la haga surgir también desde sí mismo, la haga ser libertad propia y, por tanto, luminosa para él mismo, al menos, más cercanamente.

Tras este bello análisis que de la libertad nos ofrece Rahner llegamos a una confirmación de lo dicho anteriormente: el Dios libre es luminoso en sí mismo y, aunque su resplandor ilumina toda la creación, el hombre no puede entender la libertad de Dios, a no ser que, de algún modo, sepa, por decirlo así, integrarse en esa libertad de Dios de modo que sea consciente de la iluminación del Dios libre y la «vea». Hay que decir que lo dicho sobre la libertad parte del estudio del ser humano y se refiere al hombre. A Dios no se le pueden aplicar los resultados directamente sino por analogía. Teniendo en cuenta esto, ¿cómo podrá el hombre insertarse en la libertad de Dios para, de alguna manera, entenderla? A esto ya se ha respondido indirectamente en todo lo que se viene diciendo y ahora se insistirá ahí para resaltarlo.

Una conclusión del primer capítulo fue que el hombre en cuanto se afirma como tal está afirmando a Dios. En efecto. Si el conocimiento del hombre tiende, en último análisis, a la infinitud absoluta de Dios, por su anticipación, y dicho conocer es posible porque la anticipación es una cualidad apriórica del hombre, entonces, el conocimiento del hombre es posible porque Dios es un trascendental o apriorismo del hombre. Cuando el hombre se actúa como hombre, es decir, pensando, está ya afirmando el ser de Dios ${ }^{54}$.

Lo mismo se puede decir de la libertad. La libertad del hombre, hablando en general, es su no dependencia total de las reglas de la naturaleza, a las que supera por su espíritu. El espíritu del hombre, su capacidad de abstracción, depende siempre del mundo, parte de lo finito para, al superarlo, reconocerse como infinito. Es decir, el hombre es libre porque supera lo finito de que depende. A esta superación de lo sensible, en la que el espíritu regresa a sí mismo, Rahner denomina «la libertad del espíritu» ${ }^{55}$. El espíritu produce la sen-

53. Oyente de la palabra, 129.

54. Cfr. p. 10.

55. Espíritu en el mundo. Éste es el título del parágrafo 6 del capítulo sobre la conversio ad phantasma (283-291). Concretamente 287. 
sibilidad para desbordarla y reencontrarse, no quedando apresado en la sensibilidad sino «abstraído», vuelto en sí mismo. Como se ve, la libertad del espíritu es igual a la anticipación, consistente en la tendencia infinita del hombre hacia Dios ${ }^{56}$. La libertad, por consiguiente, como anticipación, se proyecta hacia Dios como su fin. En una palabra, el hombre, en cuanto se realiza a sí mismo en lo que le caracteriza como hombre, su conocimiento y libertad, está afirmando el ser de Dios como su fundamento y autofinalización.

Ahora bien, todo esto significa que el hombre, en su esencia, es amor a Dios. Si el hombre al afirmarse necesariamente como conocimiento y libertad está afirmando a Dios también necesariamente, y el existir del hombre con sus facultades peculiares no es más que tender a Dios, quiere decir que el hombre necesariamente es amor a Dios. Y si la anticipación, tendencia hacia Dios, es una facultad a priori de la esencia humana, el amor a Dios, igualmente tendencia hacia Dios, es también una determinación apriórica de la constitución humana ${ }^{57}$. Y en este amor del hombre a Dios, que es parte del mismo ser del hombre, encontramos el punto de inserción del hombre en la libertad de Dios. El hombre es amor a Dios, identificación con Dios, aceptación del ser libre de Dios, unión a la libertad de Dios. Y por tanto el hombre puede entender la libertad de Dios, porque en su existencia se da una necesaria inserción en ella. Con todo, sigue en pie el ocultamiento de Dios pues el hombre, aunque pueda comprender la libertad de Dios, no la puede prever. Así es que no se ha hecho más que corroborar, desde otro punto de vista, aunque en el foǹdo es siempre el mismo, que el ser del hombre está abierto a la ilimitación de Dios, pero que, no obstante, no la puede dominar.

El hombre es amor necesario a Dios. Esto puede aparecer como contrario a la libertad del hombre. Es necesario decir que ese amor es algo estructural y apriórico de la naturaleza humana; pero el hombre tiene por su inteligencia distintas maneras de concretar ese hecho fijo. Pues el hombre es una mezcla de algo que le viene impuesto y libertad, su ser espíritu en el mundo, que le posibilita diferentes formas de actuarse. Para explicar esto Rahner propone el paralelismo de la anticipación valorativa con la anticipación intelectiva ya vista ${ }^{58}$. El mundo ante el que el hombre está le propone unos objetos que él ve como buenos para él y que intenta conseguir. Estos bienes los valora diferentemente, en un orden de preferencia, pues por su limitación espacio-temporal no los puede realizar todos ni todos al mismo tiempo. El hombre tiende por su

56. «La libertad del espíritu es tan sólo otro título para la posibilidad de la anticipación de la totalidad del ser (...), la posibilidad de la abstractio y de la reditio completa radica en la libertad del espíritu» (Espíritu en el mundo, 287-288).

57. Oyente de la palabra, 132.

58. Ibid., 134-135. 
ser al ser absoluto, Dios, para su plena realización, y por ello le aparece como el bien absoluto. Y así como la anticipación intelectiva, la valorativa no representa el destino que anhela pero es la condición de posibilidad para entender un bien finito, porque ella es infinita. El hombre intenta satisfacer su deseo de plenitud en los bienes concretos, pues no puede ir a Dios directamente sino a través de los bienes del mundo, del que depende. Pero por su pulsión hacia lo infinito reconoce y experimenta esos bienes como finitos y puede volver a sí mismo como libre, sin perderse en ellos. El hombre no puede dejar de decidirse sobre uno u otro bien, de usar su libertad, como tampoco puede dejar de utilizar su conocer, pues es hecho así y en este sentido no es libre; pero dentro de ese «ser hecho» puede elegir entre diferentes bienes.

Dios no es percibido claramente como valor supremo que colma las aspiraciones del hombre, como tampoco la anticipación del conocimiento humano lo representaba, y por la libertad del hombre sobre los distintos bienes, puede equivocar el camino hacia su propia realización e incluso rechazar a Dios, y en este caso se da la tremenda contradicción del hombre en la que niega y a la vez afirma a Dios, pues éste es la condición que le permite la negación ${ }^{59}$. El hombre realiza su ser libre concretizándolo en los bienes del mundo, pues su libertad no acaba en éstos sino que redunda sobre sí misma, y en cada acción libre se va haciendo para bien o para mal, se va acercando o alejando de la realidad para la que está hecho.

El hombre, pues, es amor a Dios, deseo de él, lo cual viene dado con su ser existente. Pero esto es apriórico y atemático y se exteriorizará en el mundo, en la propia historia personal, en la que, por su libertad consciente, desarrollará afirmativamente su esencia íntima o se opondrá a ella.

Aquí hemos llegado al momento de recapitular lo tratado. La conclusión del capítulo primero en que se describía al hombre como espíritu abierto absolutamente al Dios infinito y a Dios como el ser luminoso por antonomasia, llevaba a suponer que Dios sería tranquilamente abordable por el hombre y que una revelación sería inútil en este sentido. Esto se ha visto como falso, tanto desde el hombre como desde Dios. En cuanto al hombre, se reafirmó que el hecho de que el hombre exista siempre preguntando significa que existe siempre no sabiendo, su vida es una búsqueda continua. De otro lado la capacidad ilimitada del espíritu humano no es informativa. Es literalmente «capacidad», amplitud. Además, dicha capacidad está sujeta a los objetos finitos del mundo y sólo puede intentar un acercamiento a Dios mediante la negación de la finitud aprehendida.

Pero el absurdo intento del hombre de concretar a Dios era hecho patente

59. Curso fundamental sobre la fe, 127. 
sobre todo en el mismo ser de Dios, fundamentalmente misterio, cuya visión beatífica será la eterna compañía de ese misterio. El ocultamiento de Dios se nos muestra en su ser libre. La libertad absoluta de Dios designa la inexpugnabilidad de su ser, su tremenda lejanía de la más mínima veleidad humana de comprensión y previsión de su actuar.

El balance negativo que tenemos tras sopesar la probabilidad del hombre. de conocer el ser y actuar de Dios es contrarrestado por la naturaleza del hombre. Pues si un acto libre sólo puede ser entendido en cuanto que uno se inserta en ese acto libre mediante el amor, el hombre, así, puede captar el actuar de Dios, percibir un hecho como suyo, porque el hombre es necesariamente amor a Dios, sin que ese trascendental humano menoscabe su libertad racional. Con todo, aunque el hombre pueda juzgar una acción como divina, no puede, en ningún modo, preverla, y su actitud debe ser de escucha. El natural amor del hombre a Dios, cuando no lo contradice con su libertad, y su conocimiento espiritual ofrecen al hombre el poder recibir el obrar de Dios en el mundo y entender su mensaje; pero no puede predecir las actuaciones de Dios ni puede, por sí solo, lograr la inteligibilidad completa sobre Dios. De manera que una revelación de Dios tiene sentido. El hombre no puede anticiparse a una automanifestación de Dios; pero, si ésta tiene lugar, encontrará en el hombre la apertura infinita para acogerla. La siguiente reflexión deberá referirse al lugar dónde el hombre pueda encontrar una revelación que Dios le dirija. Dónde se hallará el punto de un posible encuentro humano-divino.

\section{EL ENCUENTRO ENTRE DIOS Y EL HOMBRE}

Tenemos que el hombre, a pesar de su finitud, está capacitado para oír una autorrevelación de Dios en su infinitud. Y que una revelación de Dios no es una pérdida de tiempo que el hombre podría hacer innecesaria, sino un don gratuito e inmenso. Si el hombre puede oír a Dios y Dios «puede», como posibilidad, hablar al hombre, la actitud de éste será de atención, mantener en su vida una disposición de oyente. La consecuencia es buscar dónde se dará una revelación de Dios, en el caso de producirse, o ver dónde puede ya haberse dado.

Dada la dificultad de encontrar el hombre el «lugar» apropiado de la revelación, pues parecería un condicionamiento que el hombre está imponiendo a Dios y contradiría lo ya expuesto sobre la absoluta libertad divina, Rahner procede negativamente. Lo primero que rechaza es que el lugar de la revelación sea tal que anticipe el contenido de la revelación, de manera que ya se esté restringiendo de antemano la amplitud de una comunicación divina. Lo segundo es ver el modo en que el hombre se apropiará de la revelación, que puede dividirse en dos formas: o representación exacta del contenido de la revela- 
ción o representación analógica por signos-palabras si esa revelación no puede hacerse presente en su identidad. Como la manifestación del misterio divino que el hombre pueda poseer en total inmediatez sólo se llevará a cabo en la visión beatífica, queda únicamente concebir la asimilación de una revelación posible aquí en la tierra de forma mediata, a través de un signo que represente lo que no puede ser tomado en su identidad. Como tercera negación: el lugar de la revelación no debe determinarse en base a una parte de la estructura esencial del ser humano sino fundándonos en el hombre entero. La condición espiritual del hombre en cuanto abierto al ser absoluto será una parte importantísima a la hora de fijar el lugar de una posible revelación, pero no el todo. El todo será el hombre, a quien se dirige la revelación, y el hombre no es solamente espíritu ${ }^{60}$.

\section{El hombre, lugar de la revelación}

El lugar de la revelación, por lo tanto, es el hombre. El hombre como uno, como catalizador de facultades múltiples y no en una sola de sus facultades. Habrá que detallar más el ser del hombre para desarrollar mejor la especificidad que tendrá el punto de contacto entre Dios y el hombre, y no conformarse con lo ya expresado sobre el hombre como espíritu finito. Se llega así al hombre como ser histórico, porque esa es la manera concreta en la que se desenvuelve su espiritualidad finita. El hombre no puede ser considerado más que en la historia y una revelación, si se ha de dar en el hombre entero sin olvidar nada que le sea determinante, deberá pasar por la historia. La historia es la concreta mezcla que aúna la espiritualidad y materialidad fundamentales del hombre, y una revelación, en cuanto tiene por destino al hombre, deberá confluir en su historia.

Que la revelación debía ser histórica es algo que venía por sí mismo una vez que se habló de Dios como ser libre. La historia es primariamente la consecuencia del obrar libre, y entonces la revelación, cuyo primer paso es la libertad del Dios que se manifiesta, es siempre algo histórico. Pero dado que hay que ver también el punto de vista del hombre, pues es él quien escuchará una posible revelación, la historia que se ha de analizar es la humana.

Se trata de hacer ver de forma argumental que el hombre es intrínsecamente historia, y aclarado esto quedará a la vez dicho que la revelación de Dios tendrá que ser histórica, que si el hombre debe volverse a sí mismo para escuchar lo que Dios le ha de decir, debe volverse a su historia. Para ello Rahner vuelve otra vez a la pregunta general por el ser ${ }^{61}$, pregunta que es el mis-

60. Oyente de la palabra, 147-150.

61. Ibid., 153. 
mo hombre, pues no hay otro modo de comenzar el estudio sobre el hombre sino desde la experiencia que nos acomuna a todos como seres humanos y que es la búsqueda existencial del sentido del todo y de nuestro papel dentro de él. Y esta pregunta por el ser será vista bajo el aspecto del conocer subsiguiente a dicha pregunta, porque la finalidad última de todo es ver el modo de darse la recepción que el hombre dispensaría a la revelación. Para saber dónde aplicar la atención hacia Dios se dilucida la forma humana del conocer, pues ahí se le manifestaría gratuitamente.

a) Materialidad del hombre.

La pregunta por el ser se da en todo actuarse del hombre en cuanto hombre. Todo conocimiento del hombre consiste en la inclusión de un objeto en el horizonte ilimitado del ser. Preguntar por algo es preguntar por su participación en el ser último y afirmar un predicado de algo concreto es atribuirle una cualidad del ser en general en forma limitada. La pregunta y el conocimiento del ser están presentes, se concretizan, en cada pregunta y conocimiento de las cosas. Esto ya ha sido dicho. También que ser es estar consigo y que conocer no es primeramente abarcar algo que está delante de nosotros sino estar un ente consigo, pues conocer es esencialmente ser, tener ser, según la analogía de la «posesión de ser». Pero además, el conocimiento humano, que es estar consigo, no llega a realizarse por sí mismo. Necesita de un estímulo externo. El hombre solamente puede conocer, estar consigo conscientemente, cuando hay algo que le sale al paso que le permite distinguirse de él, volviendo sobre sí mismo, y conocerlo. Lo cual significa que el conocimiento del hombre es receptivo, que todo saber suyo depende de algo externo para realizarse y que todo desarrollo de su saber seguirá sostenido por ese primer punto de partida. Hay que analizar ese punto de partida que se desglosa en la facultad receptiva del hombre y en el objeto que se le enfrenta, que son lo mismo, en la unidad esencial de conocer y ser conocido en el ser ${ }^{62}$.

Se presenta un problema. Si ser es estar consigo y conocer es el estar consigo del conocedor, de forma que ser y conocer son lo mismo, parece que lo primero que conoce el hombre es él mismo, lo que contradice lo que se acaba de decir sobre el conocimiento como primariamente receptivo de algo externo, que no es uno mismo. La contradicción ya se veía al describir el conocer pues se dice que es primariamente estar consigo, es decir, conocerse, y a la vez se dice que el punto de partida es un objeto externo. La única solución, dirá Rahner, es identificar ambos momentos: conocerse a sí mismo es conocer a lo otro y el ser del cognoscente es el ser de lo otro ${ }^{63}$. Cuando el hombre está consigo conociendo, está en lo otro. Para entender todo esto hay que tener en cuenta

62. Ibid., 154-156.

63. Espíritu en el mundo, 94; Oyente de la palabra, 161. 
la distinción metafísica del ser y el ente. Todo ente es informado por el ser, teniendo una cierta posesión del ser, y siendo más perfecto cuando mayor sea el grado de ser poseído. Si el conocer es estar en sí mismo estando en lo otro, siendo ser uno mismo y a la vez ser lo otro, eso «otro» no podrá tener ser, no estará consigo mismo. A eso «otro» vacío de ser lo llama Rahner, siguiendo la metafísica tomista, «materia». El ser del hombre, llamado en la terminología escolástica «forma», es el ser de esa realidad sin ser propio que es la materia. La materia no es algo accesorio de la forma sino lo que permite a ésta ser ella misma, y así la materia es lo que hace posible que tenga lugar la forma o ser del hombre. El ser del hombre es la realidad de lo otro, la materia, y no se puede realizar sin ella. El hombre es esencialmente materia. Y el conocer del hombre, ser de lo «otro», es ser de la materia, es un conocer sensible. Es un conocer receptivo de lo externo material, es sensibilidad, identificación con la materia ${ }^{64}$.

Si había sido dicho que el hombre es esencialmente espíritu, ahora se dice que el hombre es esencialmente materia, y la materia es expresión de la forma humana o espíritu. Ninguna puede prescindir de la otra en la realidad que es el hombre, los dos son constitutivos intrínsecos del ser humano. El hombre es espíritu en la materia, para ser espíritu necesita de la materia, se conformará como espíritu tendente al infinito por su facultad material ${ }^{65}$.

b) Historicidad del hombre.

Siguiendo la metafísica tomista Rahner conceptúa a la materia como el principio de la espacialidad y temporalidad.

Espacialidad. La materia era el «algo» vacío en el que se sitúa nuestro ser en el conocer. Era algo indeterminado en sí, no es sino cuando es tomado por el ser de otro. El «algo» con ser es la forma que determina la materia y se determina en la materia. Como la materia es algo en sí mismo indeterminado no está ordenada a ninguna forma en concreto sino a cualquiera, a todo ente con ser que puede informarla.

Espacialidad. La materia era el «algo» vacío en el que se sitúa nuestro ser en el conocer. Era algo indeterminado en sí, no es sino cuando es tomado por el ser de otro. El «algo» con ser es la forma que determina la materia y se determina en la materia. Como la materia es algo en sí mismo indeterminado no está ordenada a ninguna forma en concreto sino a cualquiera, a todo ente con

64. Espíritu en el mundo, 95; Oyente de la palabra, 165. Una crítica que se levanta en seguida en esto es si la concepción tomista del conocimiento que presenta Rahner como identidad del ser que conoce con lo conocido sin ser, o materia, puede hoy tenerse en cuenta. Se prefiere una interpretación más científica del conocer. Rahner mismo dice que la materia tomista es un concepto difícil, «no observable, no concebible como cosa», y que es algo distinto a la materia físicoquímica (Oyente de la palabra, 162-163).

65. Oyente de la palabra, 169; Espíritu en el mundo, 288. 
ser que pueda informarla. La materia es sujeto indiferente ante diversos predicados posibles o formas y la forma es algo universal que puede aparecer como predicado de la materia cuantas veces se quiera. Es decir, que la materia está abierta indefinidamente a muchas formas, que pueden llenarla repetidamente. Ahora bien, esto indica un número. Repetibilidad ilimitada es el número ilimitado de veces que la materia acoge a la forma. Un número expresa una cantidad y éstos, referidos a la materia, designan su espacialidad, su capacidad para recibir una forma repetidamente. La materia es, por tanto, espacial y un ente esencialmente material será esencialmente espacial ${ }^{66}$.

Temporalidad. El tiempo es para santo Tomás algo inherente al movimiento. Tiempo no es algo estático, formado de pasado, presente y futuro como estadios fijos a partir de un momento presente, cada uno de los cuales descansa sobre sí mismo. Tiempo es movimiento que hace brotar de sí los estadios temporales, pasado, presente, futuro, en una sucesión interdependiente. Tiempo en cuanto movimiento supone que un momento presente es tal porque tiende de un estado anterior hacia uno futuro. Todo momento actual depende de uno pasado y hace posible otro futuro. El presente se actúa concentrando el pasado en una anticipación del futuro ${ }^{67}$. La materia es una potencia indeterminada de ser. Es un vacío abierto a varias formas que le den ser, como quedó dicho. Es así algo más amplio que una forma, ésta no colma la ilimitación de su espacio. Y un ente material por su amplitud indefinida nunca colmada está continuamente en movimiento hacia nuevas posibilidades que ve delante. Se mueve buscando la realización de sus posibilidades futuras. Como las determinaciones que plenificarían las ilimitadas posibilidades de la materia se excluyen parcialmente, no pudiendo dar ser entitativo simultánemante a la misma materia, se necesitará un orden sucesivo entre ellas. El ente material que tiende a llenar sus posibilidades se verá sometido a un orden preferencial, tendrá que regular la realización de sus posibilidades, hacia las que siempre está en movimiento, en modo de sucesión. El movimiento sucesivo es lo que definía al tiempo. Por lo tanto un ente material es siempre temporal ${ }^{68}$.

Con esto queda dicho que la materia es intrínsecamente espacialidad y temporalidad y permite una repetibilidad en sí de la misma forma; y todo ente

66. Oyente de la palabra, 167, 172; Espiritu en el mundo, 112-120.

67. Espíritu en el mundo, 120-123.

68. Oyente de la palabra, 172-173. Todo esto aparece como muy abstracto. Para llegar a la espacio-temporalidad, y con ello historicidad, del hombre no se precisan pruebas argumentativas. El ser histórico es algo que todo hombre experimenta en su vida. Su existencia la ve enmarcada en un espacio y un tiempo concretos. La propia historicidad es algo evidente para la razón humana, y lo evidente no es preciso demostrarlo, o no se puede demostrar. El mismo Rahner ha comenzado sus reflexiones desde el hombre que se encuentra en el mundo y se interroga sobre ello. Ciertamente Rahner muestra que el hombre es en su esencia espacio y tiempo, pero eso también podría ser la conclusión del experimentarse como cuerpo. 
material participará de esa impronta espacio-temporal y estará abierto a la repetición en sí del mismo algo con ser. Así que el hombre, cuya materialidad ya se hizo constar, es estructuralmente espacio y tiempo y su base material permite que su forma, su ser, sea repetible, o sea, que pueden darse muchos hombres. Y como ente material que es tiene ante sí una amplitud ilimitada de posibilidades que desea colmar, pero que nunca agota ni puede realizar simultáneamente. Pero el hombre vive con otros hombres, los cuales provienen de una larga serie de comunidades humanas, gracias a las cuales son lo que son, y cuyos progresos, basados éstos en otros anteriores, transmitirán a las generaciones futuras. Es así como la humanidad va realizando las escondidas posibilidades de todo hombre como ser material.

El hombre es materia, mundo, ser espacio-temporal, lo cual pertenece a su meollo, no es algo accidental. El hombre existe inseparablemente unido al mundo, en un espacio y tiempo concretos, junto a otros hombres con los que comparte las características de un momento de la humanidad. Además el hombre es libertad, elige entre las posibilidades que se le ofrecen y se va haciendo a sí mismo en su libertad. La humanidad, formada por cada hombre singular, intenta hacer reales las posibilidades cada vez mayores de su futuro, para lo cual establece un orden en base a su necesidad y libertad. Esta evolución progresiva en el mundo de la humanidad, a la que representa y en la que se siente representado cada individuo, hacia el cumplimiento de sus crecientes posibilidades según su libertad es lo que se llama la historia humana.

Sólo hay historia donde hay libertad ${ }^{69}$. E historia humana es el desenvolvimiento de la libertad del hombre en un espacio y tiempo determinados y condicionantes, y junto al condicionamiento y complemento que supone la libertad de los otros hombres con los que se convive, de los que se proviene y a los que se servirá de fundamento, en los que se realiza como conjunto lo que cada uno posee en esencia. El hombre es mundo, su libertad es material, se da siempre en un espacio, un tiempo y junto a otras como ella, que eran tres consecuencias inherentes a la materialidad. El espacio, el tiempo y la libertad de los otros hombres son a la vez el límite y la condición de posibilidad del propio ser libre. Si la vida del hombre es el desarrollo de su libertad dentro de las coordenadas de su ser material -espacio, tiempo, repetibilidad-, que es algo intrínseco a su existencia, entonces el hombre es esencialmente histórico. La historia del hombre es libertad en el mundo. El hombre es libertad, es mundo, es por tanto historia.

De manera que, tras todo esto, hay que decir que el lugar de una revelación que puede acontecer deberá ser la historia humana, síntesis esencial de su libertad y materialidad. Ciertamente así debe ser. Se quería delimitar el lugar

69. Ibid., 175. 
de una posible revelación del Dios libre al hombre también libre. El hombre tenía que ser el lugar de la revelación, pues por la absoluta trascendencia de su espíritu no significaba ningún recorte a la infinitud de la revelación, y la permitía ser lo que es en su integridad: comunicación que el Dios absoluto hace de sí mismo. Pero el hombre no es sólo esa trascendencia absoluta, espíritu, sino también y siempre materia, en una unión indivisible con su espíritu. Esta conjunción inextricable de su espíritu y materia que es el hombre, y que no puede ser de otra manera, en una de las dos facultades sin la otra, significaba la historicidad del hombre. El hombre es un ser histórico, o es historia, y si una revelación supuesta debe dirigirse a su espíritu infinito se dirigirá también a su historia, pues el hombre en cuanto espíritu no existe en sí, sino siempre unido a la materia en una historia. Una comunicación del Dios libre acontecerá, por tanto, en la historia del hombre.

El paso siguiente de Rahner será ver de cerca esta esencialidad histórica del hombre. Cómo la historia determina o posibilita, influye, en la condición espiritual humana abierta a la infinitud de Dios.

c) $\mathrm{El}$ «fenómeno» sensible.

Para entrar en el tema de la relación entre el espíritu y la historicidad humana hay que hacer un preámbulo desde posiciones ya explicadas.

El conocimiento del hombre es receptivo, receptivo de la materia como potencia sin ser en la que el ser-conocer se hace ser de ella, idetificándose con ella. La identificación del conocedor con la materia resulta de la sensibilidad de aquél. El conocimiento del hombre es sensible. Pero el conocer humano no acaba ahí. Un segundo momento conceptual, en realidad es un conocer único, se produce cuando el ser del hombre torna sobre sí, distinguiéndose del objeto que conoce y juzgando ese objeto, aplicándole un universal en el que se le incluye, lo cual fue llamado abstracción. Por la abstracción se llegaba a que, si el pensar era un universal atribuido a un objeto singular que se tenía delante y del que se partía, el hombre en su pensar contaba con una capacidad de ver las cosas en su movimiento hacia el infinito, la anticipación o espíritu humano. Pero de la misma abstracción se concluía que no era posible la anticipación pura en el hombre, pues siempre se dependía de lo concreto para llegar, superándolo, a lo ilimitado. El hombre para ser espíritu, para ser la transcendencia hacia el absoluto que siempre es, necesita comenzar con su conocimiento sensible, receptivo de la materia, para, mediante la negación del límite, afirmar la ilimitación. El espíritu apriórico del hombre suscita de sí la sensibilidad para realizarse como espíritu. El espíritu se encuentra consigo mismo tras haberse perdido en la materia, llega a ser espíritu en cuanto que se hace también materia. Todo esto quiere decir que el hombre actúa su capacidad infinita de lo divino cuando se inserta en lo material, descubre su apertura a Dios cuando se integra en el mundo. 
Pero, ¿qué entiende Rahner por mundo? Mundo y entes materiales no debe ser entendido en sentido externo meramente, de inmediatez sensible, física, sino en un sentido metafísico de materia, al estilo tomista, que no corresponde a la materia de hoy. Mundo es así «todo lo que inmediatamente se puede ofrecer en cuanto tal a un conocimiento receptivo, a un conocimiento que capta un objeto singular real» ${ }^{70}$, que no se referirá a objetos externos sino también al hombre mismo, pues él es objeto de su recepción junto a otras muchas cosas que le rodean. Todas esas cosas que constituyen el mundo captable por un conocimiento receptivo serán tales que, según muestra la receptividad ajena, se manifestarán por sí mismas en su identidad, a lo cual se designa como «fenómeno» ${ }^{71}$. Y estos «fenómenos», al ser captables por una receptividad espiritual, que los trasciende en su tendencia al ser en general, son como el primer escalón desde donde el espíritu asciende al último fundamento de todo. Es decir, los fenómenos del mundo son para un conocimiento sensible manifestaciones del ser en general. El mundo está abierto al ser y muestra al espíritu, aunque no directamente, su estar en el ser.

Rahner concluye tres cosas. En primer lugar que «el ser en general sólo se revela al hombre en el fenómeno» ${ }^{72}$. Si la anticipación, tendencia hacia la infinitud del ser que en ello da una cierta información sobre el ser, se hace perceptible al hombre en la aprehensión de un objeto material, quiere ello decir que el conocimiento acerca del ser no se da en sí sino dependiendo de las cosas sensibles. El hombre no puede dirigirse al ser, no puede llegar a ser espíritu, más que a través de los objetos del mundo.

En segundo lugar se deduce que si el fenómeno revela al ser es porque él participa del ser, tiene cierto grado o posesión de ser. Cuando el hombre conoce un algo concreto, se dijo, lo juzga incluyéndolo en un concepto más amplio («esto es de esta clase»). Es decir, por la anticipación apriórica humana, un objeto al ser conocido, es delimitado como poseedor de manera finita de una atribución universal e ilimitada, es visto como momento del ser en general, al que no contiene más que en parte y por ello aparece como finito.

El problema que se presenta es si un algo no concreto, que mentalmente deberá ser reducido a ente o concepto particular por el hombre, pues no puede conocer de otro modo, puede ser alcanzado a través del fenómeno en algo más que en sus determinaciones generales sobre el ser, accesibles por la anticipación. Si por ejemplo de Dios puede conocerse algo específico, más que concebirlo como fundamento de todo y condición de posibilidad de nuestro conocimiento. El problema, en resumen, es si Dios puede revelarse al hombre en mo-

70. Ibid., 187.

71. Ibid.

72. Ibid., 192. 
do concreto a través del fenómeno. Si el fenómeno no sólo puede manifestar el ser de Dios en general sino también algo más determinado sobre Dios, procedente del hablar divino al hombre sobre sí. El hombre es ser histórico, trascendentalidad en la materia, y Dios, si ha de comunicarse al hombre como lugar perfecto de una revelación, se comunicará en la historia, en el espíritu humano que sólo conoce a través de la materia. Por tanto Dios se revelará al hombre en la materia, en el fenómeno. La pregunta inevitable es si esto es posible. Si lo material, finito, puede acoger la automanifestación de Diós en su infinitud para mostrarla al hombre o, mejor dicho, para que el hombre pueda recibirla desde lo fenoménico.

La respuesta de Rahner es afirmativa: «Todo ente puede hacerse presente en el horizonte del fenómeno humano mediante la palabra» ${ }^{73}$, que es la tercera de las conclusiones suyas que estamos viendo. Es también el punto segundo de este capítulo.

\section{Palabra-representación}

Todo ente, y Dios como ente de la absoluta posesión de ser, puede ser captado en sus particularidades en lo sensible para el hombre, a través de la palabra, se acaba de decir.

El hombre, por su anticipación, que parte de lo finito sensible, tiene idea del ser en general en modo vago, en sus generalidades. La anticipación no da un saber que se represente al ser en su identidad, sino en su amplitud ${ }^{74}$. Pero el ser ha aparecido, aunque sea en modo incierto, en las cosas sensibles. Lo material, el mundo, revela al ser como su fundamento, participa del ser porque proviene y está incluido en él, en suma, posee al ser. Esta posesión del ser o identificación con el ser de los entes materiales no es total; sólo Dios, concebido como ente para pensar sobre él de algún modo es la perfecta identificación con el ser, posee absolutamente el ser. El grado de posesión de ser de los entes del mundo lo establece la anticipación del conocimiento humano, que delata la presencia limitada del ser en un ente gracias a su noción de la ilimitación del ser. La anticipación, por su infinitud, conoce la medida de la posesión de ser de todos los entes, también los nos materiales, una vez concebidos como entes, aunque no lo sean, para poder juzgarlos desde su conocer. Para concretar más el conocimiento apriórico del hombre sobre el ser, que sólo es consciente en la confrontación con las cosas del mundo, deberá éste recurrir a una negación de la limitación con que ve al ser en cada ente. La negación de una reducción del ser, o de un momento del ser que transparentan las cosas, se

73. Ibid., 199. Para lo anterior 196s.

74. «[la ilimitación del ser en general] en la anticipación sólo se puede experimentar como ausencia de un determinado límite, pero no en su infinitud en sí» (Ibid., 203). 
convierte en una afirmación del ser, y tambien en una afirmación de un ente con una limitación menor de posesión de ser, aunque sea de un ente extramundano. Según Rahner todo ente, aunque no sea mundano, puede ser conocido a partir del fenómeno sensible por su relación común con el ser ${ }^{75}$. La anticipación del hombre conoce la posesión de ser de un ente sensible. Por la negación del límite expresado en esa posesión del ser accesible inmediatamente a nuestra receptividad llegamos a otros entes no sensibles de una mayor posesión de ser y a Dios como cima, identificación con el ser.

Esta negación se realiza por la «palabra». Palabra como concepto, como imagen de un ente no sensible, que se obtiene mediante la negación del ente sensible ${ }^{76}$. La negación de la limitación que lleva lo sensible sirve para afirmar un concepto-palabra sobre algo otro sin esa limitación. La palabra o concepto, aun procediendo de una negación, muestra algo, afirma un ente, aunque no esté bajo lo fenoménico. Por consiguiente aparece como cierta la conclusión que decía que todo ente puede ser captado en los fenómenos mundanos mediante la palabra.

Dios, ente supramundano, podrá, según esto, ser captado desde los fenómenos del mundo. Las cosas materiales pueden mostrar la infinitud de Dios al hombre en modo más específico por Ia palabra negadora humàna. Dios, por consiguiente, puede revelarse al hombre en el fenómeno, que no supondrá restricción alguna a la revelación, pues la negación que brota del conocer del hombre en la palabra se abre al ente absoluto. El lugar de la revelación, el punto de coincidencia entre Dios y el hombre, donde el hombre debe centrar su atención, será, entonces, la palabra humana. No es necesario esperar una revelación de Dios de otro modo, sin tener en cuenta la palabra, pues destruiría la estructura cognoscitiva humana, y sería como inútil dado que el hombre puede entender el hablar de Dios desde la misma constitución antropológica que experimenta en sí.

La palabra del hombre es el lugar de la revelación. El espíritu y la materia, hombre, escuchan a Dios. El conocimiento humano, la palabra, expresión del conocer mental, puede recibir a Dios por su síntesis de espíritu y materia en una vuelta al espíritu consciente, concebido concretamente en su saber por la negación de la finitud material. La palabra humana, «síntesis de una objetalidad histórica intramundana y de una negación trascendental» ${ }^{77}$, expresará todo lo que Dios le puede decir de sí.

75. Rahner pone el ejemplo de un campo geométrico donde partiendo de puntos claros se podrán fijar otros puntos del campo relacionados con los primeros (Ibid., 201).

76. «... en la palabra que naturalmente no equivale a un sonido fonético (...) se puede aprehender todo ente extramundano. En efecto, la palabra por una parte no representa al ente en su identidad, y por otra parte mediante la negación que ella, y sólo ella, puede asumir en sí, la palabra tiene la posibilidad de determinar en función del fenómeno a todo ente» (Ibid., 204-205).

77. Ibid., 206. 
La revelación por ser un acto libre de Dios es ya historia en sentido metafísico. Pero si esa revelación es destinada al hombre deberá entrar en la historia humana, que es una conjunción insuprimible de espíritu y mundo. Para que el hombre pueda recibir el mensaje libre de Dios, éste deberá discurrir en lo histórico intramundano, integrarse en la espacio-temporalidad de la historia humana como un momento, un «punto» en palabras de Rahner, de ella ${ }^{78}$. El hombre a lo largo de su vida conservará, mediante la negación de la finitud inherente al espacio y tiempo expresada en la palabra, esa revelación de Dios volviéndose al instante en que la divinidad se le hizo presente. Para justificar que la revelación libre de Dios tenga que darse en un «punto» de la línea histórica del hombre Rahner parece argüir que la historia humana son instantes sucesivos, en que cada uno de ellos se apoya en el anterior y posibilita el siguiente, pero nunca son el «mismo» instante. Una revelación de Dios que se concretice en la historia del hombre tendrá lugar en un punto de esa historia, no en todos pues no son iguales. Esa revelación bastará dada la continuidad de la historia humana por la que el hombre siempre podrá referirse a ese punto en la sucesión de instantes que forman su vida ${ }^{79}$.

La consecuencia que se saca, una vez conformes con lo anterior, es que, dentro de la lógica histórica del hombre, no será necesario que la revelación se produzca en un momento de cada historia humana individual sino en un momento de la entera historia de la humanidad. Porque el hombre experimenta que su historia particular se asienta en una historia anterior que hace posible que su historia, siempre en unión con la de otros hombres contemporáneos, sea como es, y que la contribución de su época histórica, de la que es parte integrante, no morirá con él sino que será continuada y desarrollada por otros. La historia de cada hombre no es sólo una concatenación de instantes particulares sino de instantes generacionales. De modo que la continuidad de la concreción de la revelación de Dios a todos los hombres se salva insertándola en un punto de toda la historia humana, no hace falta una determinación en cada historia particular. Es una nueva condición mínima, pues un momento de revelación a unos hombres, captado y expresado por éstos como tal, será accesible a la historia humana posterior.

78. Ibid., 208.

79. «Así la revelación se produce por lo pronto en forma de historia humana al menos en el sentido de que no puede coexistir siempre igualmente con todos los momentos particulares de una historia humana individual, de modo que el hombre, para captar la revelación, deberá en un conocimiento histórico, volverse con una mirada retrospectiva por lo menos a determinados puntos destacados en su propia historia» (Ibid., 209-210). Con ello Rahner mantiene la estructura de la historia humana y el mínimo de una concreción espacio-temporal de Dios. Si una revelación divina se ve plenificada así suficientemente no se ve para qué deba romper la irrepetibilidad esencial de la historia del hombre con intervención concreta repetida de Dios en distintos instantes. 
El problema claro que surge es que si bien un punto de la historia general del hombre donde se dé la revelación puede ser conocido por la historia posterior, puede también no ser conocido por una parte de la misma, y más claramente podrá ser desconocido por el período anterior a ese momento de revelación. Con todo, Rahner así ha mostrado que el hombre dispuesto a la escucha de una revelación divina deberá atender a la historia humana global, pues en ella se cumplen de modo mínimo todas las condiciones imprescindibles para el contacto de la palabra divina con el oído humano ${ }^{80}$.

Hemos visto, pues, en esta sección que el hombre es materia. y, a la vez espíritu en indivisible conjunción. Esto ya se había dicho al hablar del hombre como espíritu y hombre como mundo. Pero aquí se matiza que esa síntesis corpóreo-espiritual que es el hombre se concibe como historia. El hombre es histórico: una libertad que actúa y se actúa en los fenómenos sensibles.

Se buscaba el lugar de la automanifestación infinita de Dios. No podía ser otro más que el hombre por la capacidad de infinito que poseía su espíritu. Pero como el hombre es también materia, y consecuentemente historia, y su espíritu no es sino en la materia, la recepción que el espíritu humano pudiese dispensar al Dios absoluto no sería sino en la materia, y consecuentemente en la historia humana. El lugar de la revelación se hallaría en la historia.

El problema era si la historia del hombre, realizada a partir de lo fenoménico material y evidentemente limitada, no comportaría una disminución de lo que Dios quisiera decir. La solución, de algún modo, ya se había dicho también antes: llegado a la consciencia de su espíritu y de su contenido ilimitado, desde los objetos del mundo, el hombre reflexionaba y delimitaba más su saber informe espiritual con la experiencia trascendental del límite. El hombre mediante los fenómenos materiales sabía, negándolos en su finitud, afirmar conceptos sobre algo no mundano, por ejemplo Dios, lo cual llamamos palabra. La posibilidad de la negación de la finitud se veía en la apriórica infinitud

80. Rahner dice en «Oyente de la palabra» que su cuestión no trata de ver cómo el hombre puede recibir una revelación ya ocurrida sino por qué el hombre debe buscar una revelación posible en la historia de la humanidad (Ibid., 211).

A la cuestión ulterior de cómo el hombre puede reconocer en su historia la palabra de Dios en forma de palabra humana Rahner contesta que si se llega a lo extramundano mediante un fenómeno cuya negación lo explicita, quizá el milagro entendido no sólo en lo físico mostraría la objetividad de una negación. El «milagro» sería la negación del fenómeno dirigida al hombre ya atento a una negación para encontrar a Dios. El milagro es así signo objetivo de la revelación hecha historia (Ibid., 214-215). Y a la segunda cuestión de cómo conectar con la revelación histórica si ésta está temporalmente muy alejada, Rahner distingue entre tiempo físico, que puede suponer realmente mucha distancia respecto a la revelación, y tiempo interior del hombre, que puede hacer «simultáneo» un hecho histórico «pasado». Mediante la «tradición» un hecho histórico se mantiene y se entrega a través de las generaciones, se actualiza para cada época (Oyente de la palabra, 215-216). 
que conforma el conocer del espíritu humano. De manera que la historia mundana, material, del hombre no mermaba la plenitud divina, porque la historia del hombre es también espíritu y el espíritu remontaba la cortedad de lo material con la negación de la palabra hacia la anchura sin límites, encontrándose a sí mismo. La revelación de Dios podría perfectamente descansar en lo sensible para hacerse accesible al hombre; el espíritu humano impediría que quedase ahí aprisionada, liberándola en la negación trascendental o palabrarepresentación.

En conclusión, el lugar de la revelación, encuentro entre Dios y el hombre, estaría en la historia humana, historia que en su esencia no se reduce a la existencia particular sino que se alarga a la historia una de los hombres. El hombre debe observar su historia si quiere oír la palabra que Dios le dice, que se exteriorizará en la palabra humana.

\section{LA COMUNICACIÓN DIVINA}

La creencia cristiana en una revelación divina y realizada ha encontrado la fundamentación filosófica de su posibilidad en una antropología teológica. El hombre es, desde que es hombre, un ser que se apresta a una donación del mismo Dios en la tierra, en su historia. Donación de la que, por otra parte, no puede apoderarse, a pesar de la trascendencia de su espíritu, porque su trascendencia es material. Y también por el ser de Dios, misterio impenetrable y libertad absoluta, que hace impensable la idea de ser comprendido por la inteligencia humana. El hombre no puede hacer otra cosa más que esperar el favor divino de su amor libre en una manifestación propia; la naturaleza humana sabrá entenderla transformándola en palabra suya.

Falta por analizar la comunicación divina en sí misma. Hasta ahora se ha dejado constancia de la facultad del hombre de acoger una revelación de Dios, de su necesidad como acción de Dios, caso de darse, porque no será nunca sola acción del hombre, y de su concreción en la palabra humana. Ésta es la parte más importante de este trabajo. Como complemento a esto no estará de más exponer el funcionamiento, por decirlo de algún modo, de la revelación según la concibe Rahner.

\section{Gracia, fe, historia de la salvación.}

Una de las características que resaltan en el pensamiento de Karl Rahner es la unidad en que concentra las verdades cristianas y sus consideraciones sobre ellas: Dios como centro primero y último de la reflexión teológica, punto de partida y de llegada del que brotan y al que apuntan todas las cuestiones es- 
pecíficas del entero pensamiento religioso cristiano ${ }^{81}$. Teniendo en cuenta esta concentración de la múltiple problematicidad teológica en Dios como protomisterio vamos a ver la relación que Rahner propone entre la revelación, que originariamente es Dios mismo que se comunica, y la gracia, fe e historia de la salvación. Esto es importante porque si todas las cuestiones de la teología en último análisis tienen a Dios como origen habrá que compararlas entre sí, una vez conceptualizadas concretamente, para descubrir su singularidad.

a) Gracia, fe y revelación.

Gracia es don, favor de Dios. Está, pues, íntimamente unida al ser de Dios. No puede ser pensada fuera de esta conexión. Ésta es la doctrina de Pablo y de la patrística. La reflexión sistemática que se inició en la escolástica sobre la gracia supuso un problema difícil tanto para la época suya como para las posteriores, herederas de sus deducciones. Al estudiar la gracia en sí misma, opción legítima, se corría el peligro, que se fue agravando con los siglos, de separarla de Dios. La «gracia» era «algo» que daba Dios y que funcionaba eficazmente en el hombre. Había varias clases de gracia, cada una con un efecto propio. De otro lado la gracia fue también separada de la realidad humana. La insistencia en su eficacia desestimó el ser libre del hombre y su decisión. La gracia quedó aislada entre Dios y el hombre y así se desvirtuó la noción primera de gracia, regalo de Dios de sí mismo al hombre que pide su aceptación libre.

Rahner es partidario de volver a la idea primigenia de la gracia: Gracia es don de Dios, esencialmente unida a Dios, pues consiste en la donación del mismo Dios. Dios en la efusión de su gracia no da algo al hombre sino que se da a sí mismo. La gracia es la autocomunicación de Dios al hombre que interpela a la libertad del hombre a la decisión ${ }^{82}$. Así la gracia no es tampoco algo que actúa en el hombre pasivo, como una fuerza extraña que la empuja, aunque la gracia también es eso, pero sólo cuando el hombre se ha decidido por ella. La gracia requiere la aceptación y asimilación por parte del hombre para su plenitud.

81. «Los misterios cristianos (...), en plural, son modificaciones internas del misterio único ante el cual la doctrina cristiana de la revelación coloca al hombre» (Escritos de Teología, IV, 53). Los misterios cristianos y por extensión los problemas teológicos «no son esencialmente nuevos misterios que, comparados con este protomisterio, lo superen, sino a lo sumo podrán ser derivados secundarios suyos (...).

Los misterios singulares no parecen ser verdaderamente misteriosos en el sentido original de la palabra, porque no parece que dejen al misterio descansar sobre sí, sino que pretenden con curiosidad saber algo determinado sobre él» (Ibid., 83-84). En este artículo Rahner considera que no podemos hablar de innumerables misterios en el cristianismo. Misterios «stricte dicta» se reducen a la Trinidad, o Dios en sí mismo, y la Encarnación y gracia de Dios al hombre, que fundamentalmente son lo mismo: la autocomunicación de Dios al hombre (Ibid., 89-91).

82. RAHNER, «Gracia», en Sacramentum mundi, III, 320-323; Escritos de Teología, I, 336, 341. Curso fundamental sobre la fe, 209. 
Pero si, según Rahner, la gracia es la autocomunicación de Dios en el amor, y que por ser gracia ya se indica que proviene de la libertad de Dios, entonces, el concepto de gracia coincide con el concepto de revelación que ya se explicó, también autocomunicación de Dios libre. Rahner hace explícita esta identificación. La revelación, cercanía absoluta de Dios al hombre, como la gracia, no consiste principalmente en algo distinto de Dios sino que es Dios mismo ${ }^{83}$. La gracia y la revelación están totalmente ligadas entre sí, pues la gracia, Dios en el hombre, conlleva comunicación de misterios, en el único misterio que es Dios, y la revelación solamente puede acontecer en la gracia ${ }^{84}$. La revelación es siempre una gracia de Dios que se dona incondicional y libremente y la gracia de Dios es siempre una autocomunicación del ser de Dios al hombre.

Pero si, básicamente, revelación y gracia son la misma cosa, también hay que establecer una cierta diferenciación. Se acaba de decir que la revelación sólo puede darse en la gracia, en el hombre ya divinizado por la gracia, de manera que la gracia es un presupuesto de la revelación, y por tanto algo distinto. Esto se puede entender si se tiene en cuenta la división con que Rahner desarrolla su doctrina sobre la revelación. La revelación es, de un lado, autodonación de Dios al hombre, que siempre está en él en su espíritu; y la revelación es también una autointeriorización consciente del hombre, reflexión sobre su apertura a Dios que el hombre expresa en su palabra. Al primer tipo Rahner la llama revelación trascendental y al segundo revelación categorial. La gracia se identifica con la revelación trascendental, Dios que se comunica al hombre, y puede distinguirse de la revelación categorial, plasmación en palabra humana de la comunicación divina, de la que la gracia o revelación trascendental es presupuesto, sin romper, por tanto, su concatenación y unidad esencial.

Considerando este punto de vista de la diferenciación desde la gracia puede decirse algo parecido: la gracia es el término de la revelación y, entonces, tenemos una distinción entre ellas. Aquí Rahner está entendiendo gracia en su sentido de plenitud definitiva, la donación de Dios perfecta e inmediata que será la visión beatífica, la cual, sin duda, es el sentido último de la revelación de Dios al hombre terreno. Dios se manifiesta, se dona al hombre peregrino en el mundo como amor que supera todo y que aguarda al final de todo, invitándole a la comunión suma con él en la vida escatológica. Pero la gracia es también entendida como ofrecimiento de Dios al hombre terreno que se mantiene permanentemente a lo largo de su existencia y la determina como centro más íntimo de ella, lo que Rahner llama «existencial sobrenatural» ${ }^{85}$ que es lo mis-

83. Curso fundamental sobre la fe, 209.

84. Escritos de Teología, IV, 57, 67; Oyente de la palabra, 38 nota 6, 98 nota 3.

85. Cfr. RAHNER, «Existencial sobrenatural», en Sacramentum mundi, V, 67; también 
mo que la revelación trascendental. La oferta de la gracia o existencial sobrenatural cuando es aceptada por el hombre deriva en la gracia plenificada, encuentro entre Dios y el hombre, y aunque no es visión beatífica sí es su comienzo. De modo que la gracia como presencia de Dios en la existencia del hombre se iguala a la revelación trascendental.de Dios, y la gracia como donación directa de Dios en la visión beatífica es la culminación de la revelación terrena, lo que supone un desnivel entre ambas pero también una continuidad, pues el compromiso existencial del hombre que asiente a la oferta de Dios, consumación de la gracia, "es en el fondo visión beatífica» ${ }^{86}$.

Todo esto representa una de las peculiaridades de la teología de Rahner: la aseveración de la unidad fundamental que todas las concepciones teológicas guardan con Dios, del que nacen y en el que desembocan, y la distinción clara y matizada que pone entre esas concepciones al estudiarlas detenidamente por separado.

En esta misma línea de unidad de los conceptos sin su confusión hay que colocar la relación entre fe y revelación. El problema es ¿qué es antes la fe o la revelación? De un lado es claro que la revelación debe preceder a la fe, porque la fe significa creer en el Dios que se comunica. De otro lado se requiere que la fe anteceda a la revelación, porque una manifestación de Dios, que tiene lugar en la historia humana, necesita para ser captada como tal, un cierto conocimiento anterior del hombre sobre Dios que le permita «re-conocer» que, efectivamente, tal hecho de la historia muestra una actuación de Dios en ella; la revelación sólo es posible en el hombre que tiene fe ${ }^{87}$.

La aparente contradicción de la mutua precedencia entre fe y revelación se resuelve con las distinciones ya indicadas. La revelación trascendental, Dios insertado desde siempre en la existencia de cada hombre, en forma tal que significa un existencial intrínseco suyo, era la condición de la revelación categorial en lenguaje humano. La fe como presupuesto de la revelación, lo es de la categorial, y se integra en la revelación trascendental: el existencial sobrenatural del hombre, tener delante de su vida a Dios, incide en la naturaleza humana abierta a él implicando una afirmación oscura, prerrefleja, de Dios, que es la fe. Y la revelación como presupuesto de la fe se refiere a la fe consciente, re-

Curso fundamental sobre la fe, 159-162; Escritos de Teología, I, 330 nota 4, 342; GARCía-MuRGA, op. cit., 55.

86. Escritos de Teología, IV, 77.

87. Curso fundamental sobre la fe, 177, 185; Escritos de Teología, IV, 67. Resulta esto asimismo en el curso 82-83 de Alfaro sobre la revelación (Apuntes: «Teología de la revelación cristiana», capítulo I, sobre todo p. 3) en la correlatividad que señala entre fe y revelación. La revelación sólo se cumple en la fe, que suscita Dios, y la revelación, a su vez, produce la fe. Revelación es acción salvífica de Dios en la historia, experimentada como tal por una comunidad creyente, que luego expresará en palabras de fe esa experiencia. 
fleja, coincide con la revelación categorial, pues el lenguaje afirmado por una comunidad creyente es un lenguaje de fe, creído, y es hecha posible por la revelación trascendental.

Rahner así, desde la unidad y diferenciación de la revelación trascendental y la revelación categorial, deduce una correspondiente diferencia y unidad de la fe en trascendental y categorial ${ }^{88}$. Se podría decir, esperando no oscurecer la cuestión, que la fe trascendental debe preceder a la revelación categorial y que, a su vez, la fe categorial es precedida por la revelación trascendental. La unidad en que, con todo, se asienta tanto la revelación como la fe hace lógico y comprensible que se pueda hablar de la recíproca dependencia entre fe y revelación.

b) Historia de la salvación e historia de la revelación.

Antes de pasar al aspecto histórico tenemos que incluir el concepto de salvación en la unidad y distinción que hemos observado en los conceptos de gracia, fe y revelación. La revelación originaria o trascendental, donación de gracia de Dios al hombre que comporta una fe preconceptual, es la comunicación que Dios nos hace de su amor, de él mismo. Comunicación que tiene la finalidad de poner al hombre frente al amor infinito de Dios, llamándolo a una aceptación de ese amor para conseguir la comunión con éli; comunión que será plena en la otra vida, pero que ya en ésta es posible, aunque en modo frágil e imperfecto, como encaminamiento hacia aquélla. De manera que la finalidad de la revelación es la salvación eterna; pero no sólo eso, pues la revelación al hombre existente es ya comunicación de salvación, que el hombre hace efectiva, como inicio, cuando la acoge, pues le pone en el sendero que conduce a ella. El hombre se encuentra constantemente en su vida ante esta oferta de salvación. Es un existencial permanente de su ser que supone la posibilidad de autorrealización de su deseo de Dios ${ }^{89}$.

Hablando desde Dios la revelación es historia, pues revelación es el obrar libre de Dios y lo que define a la historia es la libertad en lo que tiene de nuevo e incalculable, que en el caso de Dios halla su máxima expresión. Desde el hombre la revelación es asimismo historia, no puede realizarse más que en la historia humana, pues el hombre no recibe nada sino en la historia mundana de su libertad. La revelación de Dios es destinada a todos y cada uno de los hombres en su historia, pues es un existencial sobrenatural del hombre, y, por tanto, la revelación está destinada y se da siempre en la historia de la humanidad, que puede aceptar o no esa revelación. Así podemos hablar de historia de

88. RAHNER, «Revelación», en Sacramentum mundi, IV, 100.

89. «La propia oferta de Dios, en la que él se comunica absolutamente a la totalidad del hombre, es por definición la salvación del hombre, ya que es la consumación de la trascendencia del hombre, en la que éste se trasciende a sí mismo hacia el Dios absoluto» (Curso fundamental sobre la fe, 177). 
la revelación de Dios al hombre en cuanto que es objeto de acogida o repulsa en la historia de los hombres. La historia de la revelación, y por consiguiente historia de la salvación o historia de la gracia, acontece en la historia humana, coincide con ella. Esta coincidencia de la historia de la salvación-revelación con la historia de la humanidad no significa que haya una identidad entre ambas, pues la historia de la libertad humana supone la posibilidad de un no a Dios, y esa historia se convierte en historia de la perdición ${ }^{90}$.

La historia de la salvación coexiste con la historia humana y, cuando no es historia de la perdición, se unen de tal modo que, dice Rahner, es imposible al hombre distinguirlas: la acción salvífica de Dios en el hombre es acción salvífica del hombre, en el mérito del hombre Dios corona su propia obra, pues la libertad del hombre es sostenida por Dios. Pero la aceptación o rechazo humanos a la comunicación de Dios no es deducible de forma inequívoca a través de la historia ${ }^{91}$.

Quiere ello decir que existe revelación desde que el hombre es hombre, la vida de cada sujeto humano se halla ante la salvación que Dios le ofrece. La revelación no comienza, por ejemplo, con Abraham o Moisés sino con el hombre, con todo hombre; se da revelación dondequiera que exista una historia individual y colectiva de la humanidad. Y esto no sólo se debe entender a la manera de una revelación «natural», conocimiento que todo hombre tiene de Dios por su propia naturaleza con la que por sí solo llega a saber algo de Dios, sino también en el sentido de revelación del mismo Dios libre, revelación gratuita e indebida, no exigida ni inferida por la sola naturaleza del hombre ${ }^{92}$.

Que existe revelación dondequiera que existe el hombre es un postulado que Rahner encuentra implícito en la dogmática católica. Ésta afirma la voluntad salvífica de Dios y la considera universal, por tanto, para todos y cada uno de los hombres, lo cual no quiere decir que todos se salven, pues el hombre es ser libre que puede arruinarse por su libertad culpable. Voluntad salvífica universal significa la posibilidad que Dios concede a cada hombre, entregándose totalmente a él, de su salvación definitiva, cuyo principio está en la tierra de modo germinal.

Lo mismo se concluye partiendo de la libertad y responsabilidad del hombre para su salvación, afirmada desde siempre por la doctrina católica. Según Rahner el hombre es libertad y se realiza o destruye en su libertad, que le acerca o le aleja de la consumación perfecta de su ser libre en la vida eterna. La salvación supone automáticamente la libertad del hombre, el hombre obra en

90. Curso fundamental sobre la fe, 177; también «Revelación», en Sacramentum mundi, VI, 81 .

91. Curso fundamental sobre la fe, 177-178.

92. Ibid., 179-180; cfr. también Escritos de Teología, I, 326-346. 
la tierra de cara a su salvación ${ }^{93}$. Y si esta salvación no puede prescindir de la libertad del hombre para aceptarla, entonces el hombre deberá conocerla, pues de otro modo no la puede elegir.

Por consiguiente, la exigencia de libertad humana de la salvación que Dios ofrece implica un conocimiento previo del hombre de esa oferta salvífica. Si la salvación de Dios es universal todo hombre deberá conocerla para aceptarla. Ese conocimiento no estará basado en algo escrito, tipificado como clara revelación divina, pues la historia de las religiones ha visto distintas objetivaciones de revelación, que no se han extendido a todos los hombres. El saber de la revelación divina en cada hombre será más bien algo apriórico, dado en todo hombre como parte estructural de su ser, que Rahner ha denominado revelación trascendental, lo cual será necesariamente expresado pues el hombre es una vivencia mundana o externa de su interioridad espiritual. Esta necesaria exteriorización de la intimidad humana — no en sentido de exterioridad física sino subjetiva o consciente - tampoco quiere decir que toda expresión religiosa del hombre responda exactamente a la revelación interna de Dios, pues el hombre vive siempre en un mundo amenazado por la culpa ${ }^{94}$ que influye en sus decisiones y puede dar lugar a una interpretación falsa y abusiva de la revelación de Dios. Con todo, detrás de las religiones como expresión de creencias y esperanzas del hombre está el Dios que se dona a su criatura, no depende del hombre sólo, y esta donación divina es universal, alcanza a todo hombre, es el mismo hombre, y no puede circunscribirse a la revelación cristiana en el Antiguo y Nuevo Testamento ${ }^{95}$.

\section{La revelación}

¿Cómo entiende Rahner concretamente la revelación de Dios? La revelación, como ya hemos visto, consiste fundamentalmente en la automanifestación de Dios al hombre. La revelación es una o única, es el mismo ser divino volcado hacia el hombre. Esto no impide que Rahner, al detallar su análisis de la revelación una, la divida sin destruir su unidad esencial con unas notas o momentos específicos distintos, que ya han sido nombrados. Son el momento «trascendental» y el momento «categorial». «Trascendental» en la teología de Rahner referido al hombre expresa las condiciones de posibilidad del hombre mismo para que pueda ser llamado hombre. Designa lo apriórico del ser hu-

93. «Salvación no operada con libertad no puede ser salvación» (Curso fundamental sobre la fe, 182). Cito de memoria una conocidísima frase de san Agustín: «Dios que te creó sin ti, no te salvará sin tì».

94. Curso fundamental sobre la fe, grado $3 .^{\circ}:$ «El hombre como ser radicalmente amenazado por la culpa», 117-146.

95. Ibid., 181, 183; Oyente de la palabra, 233 nota 10. 
mano, que nace con el hombre y no puede no darse donde se da el hombre. Aplicado a la revelación indica que la automanifestación de Dios se da siempre en todos y en cada uno de los hombres como formando parte de su ser a la manera de un existencial, o sea, algo que pertenece siempre a la existencia del hombre, y que Rahner ha acuñado como «existencial sobrenatural». En cuanto al término «categorial», el verbo griego «kategoréo», del que obviamente procede, significa entre otras acepciones «expresar, enunciar, afirmar». Por tanto el adjetivo «categorial» referido a la revelación quiere decir revelación expresada, enunciada, afirmada, y así es como lo emplea Rahner. Cuando habla de revelación categorial está señalando el aspecto externo de la revelación en cuanto escrita o expresada en el lenguaje, la cual procede de la revelación trascendental manteniéndose así su unidad.

$\mathrm{Al}$ exponer las características que Rahner atribuye a la revelación hay que tener en cuenta todo lo dicho hasta aquí. Se vio en principio que el hombre, en lo que su ser tiene de distintivo, conocimiento y libertad, estaba capacitado para entender y acatar una comunicación de Dios, cualidad que Rahner también conoce por «potentia oboedientialis» ${ }^{96}$. Y después cómo el hombre podría encontrar esa revelación basándose en sí mismo. Pero la apertura del hombre a Dios en su manifestación, inferida con argumentos lógicofilosóficos, no podía decir nada sobre el hecho mismo de la revelación, aparte de mostrar también desde Dios la racionalidad de su posibilidad. $Y$ es que la revelación de Dios no se puede demostrar como hecho, pertenece más bien al ámbito de la fe. Con la doctrina católica sobre la realidad de la acción salvífica universal de Dios Rahner llena el vacío que deja la elucubración racional, que afirma la capacidad positiva del hombre para recibir un mensaje divino (en caso de producirse), y la manera de cómo el hombre debería buscar la palabra de Dios en sí mismo como lugar que es de la revelación (en caso de que se haya producido).

a) Estructura de la revelación.

La primera división que hace Rahner de la revelación queda fijada en revelación «natural»y revelación «auténtica» ${ }^{97}$. La revelación natural según la teología tradicional católica expresa lo que el Vaticano I dijo explícitamente (DS 3004) citando Rom 1,20: que el hombre por la sola luz de su razón puede llegar a saber la existencia de Dios. No es otra cosa lo que Rahner dice de la revelación natural.

96. Cfr. RAHNER, «Potencia obediencial», en Sacramentum mundi, V, especialmente p. 519: «Aparece ya en Tomás de Aquino y Pedro de Tarantasia (...). Significa la posibilidad que la criatura tiene, aceptando obedientemente la disposición y poder operante de Dios, de recibir una determinación de su ser, en orden a la cual no posee una 'potencia' tal que aquélla le sea 'debida'». También Oyente de la palabra, 37.

97. Curso fundamental sobre la fe, 207. 
La revelación natural se llama así porque es algo que el hombre tiene en su naturaleza racional, con la que, y sin ayuda de nada más, puede conocer la existencia de Dios. Sin embargo sigue siendo revelación de Dios porque Dios es quien ha creado esa naturaleza humana, dándose, de algún modo, en lo que ha creado. Pero esta creación por parte de Dios del hombre como espíritu encarnado, gracias al cual puede afirmar el ser de Dios, no puede por sí mismo descubrir mucho más del ser de Dios. Afirma que Dios es, pero no lo que Dios es; afirma el ser de Dios como misterio, como infinitud absoluta ${ }^{98}$. Y esta luz natural del hombre corresponde a lo dicho en la parte sobre el ser humano como espíritu. Por su espíritu el hombre está abierto a la inmensidad de Dios, cảda acto de su conocer sobre algo finito y saberlo como finito era posible por el apriorismo ilimitado en dirección a Dios que poseía, llamado anticipación. En cada acción de su conocimiento y libertad el hombre estaba afirmando a Dios como condición de su posibilidad. Pero esta anticipación hacia Dios no contenía ninguna representación, no era algo concreto, más que la indicación de la absolutez inabarcable de Dios ${ }^{99}$.

La revelación natural está en la trascendencia del espíritu o razón del hombre. Más que un verdadero conocimiento de la esencia de Dios en sí, es una disposición para recibir una autodonación de Dios, de la que sería capaz por la ilimitación de su espíritu a pesar de que dependa intrínsecamente de lo finito. La naturaleza humana es potencia obediencial para la gracia sobrenatural de una autocomunicación de Dios, que colmaría el potencial de la naturaleza humana, pero que ésta no puede exigir sino sólo tomarla obedientemente una vez que se hubiese producido ${ }^{100}$.

Analizando, pues, la estructura del hombre tenemos en él una revelación natural, un saber confuso sobre Dios en su misma naturaleza dado en la creación. Ahora hay que partir de la fe cristiana, que nos asegura una voluntad salvífica de Dios dirigida a todos los hombres. Esta presencia del amor libre divino, que acompaña la vida de cada hombre, es la revelación «auténtica» de Dios, que no procede de la naturaleza creada humana sino que es un actor propio y libre de Dios.

La revelación auténtica de Dios se fundamenta en el ser mismo de Dios como amor infinito que busca la adhesión del hombre a la comunión íntima que le propone. Es distinta de la revelación natural y la consuma. Es una acción libre del Dios amor, inderivable desde el hombre, que plenifica la capacidad y aspiración del espíritu humano. Existe simultáneamente con el mismo hombre y aunque no es algo de la misma naturaleza del hombre, de modo que

98. Ibid., 208.

99. Véase p. 10 de este trabajo.

100. «potencia obediencial», en Sacramentum mundi, V, 519. 
teóricamente podría hablarse de una «naturaleza pura» del hombre sin la gracia, en la realidad se da con la naturaleza creatural del hombre formando parte de ella como su centro más profundo, de manera que no es posible diferenciarlas en la práctica ${ }^{101}$.

b) Revelación trascendental.

La revelación auténtica de Dios es dividida por Rahner en revelación trascendental y revelación categorial o histórica, que son distintas entre sí y a la vez componen la única revelación en general propia de Dios ${ }^{102}$. La revelación trascendental supone lo que se acaba de decir sobre la revelación auténtica. Rahner la llama trascendental para insistir en su carácter interior en el hombre diferenciándola de la categorial, en la que el hombre la expresa en palabras, pero que sigue siendo revelación auténtica de Dios, pues él es quien está detrás y sustenta la conversión humana en lenguaje propio.

Así pues, revelación trascendental designa la comunicación del amor de Dios en cuanto puesta en la interioridad del hombre. Trascendental indica que es apriórica, que es un elemento innato de la realidad humana. Todo hombre la posee como posee la existencia. No es, sin embargo, una exigencia de la naturaleza humana, a la que Dios queda obligado, sino que es algo indebido que Dios concede gratuitamente en su amor. Revelación trascendental es Dios mismo introducido en el proyecto de autorrealización que es la existencia humana. En ella «Dios se le comunica en su realidad más propia, con su luminosidad espiritual, y confiere al hombre como trascendencia la posibilidad de recibir y oír esa autocomunicación y apertura personales y de aceptarlas en la fe, la esperanza y el amor» ${ }^{103}$. Se encuentra entre los existenciales permanentes que determinan la realidad del hombre terreno, pero es además sobrenatural, dado de lo alto, no originado desde la naturaleza humana, aunque la naturaleza humana lo contiene siempre. Como existencial que es esta revelación condiciona el vivir de todo hombre. Cada acción humana es una aceptación o rechazo del Dios que cubre el horizonte apriórico e ilimitado de su espíritu, aunque él no lo haya identificado históricamente en lo que es.

Esta revelación es lo que en términos cristianos es conocido como gracia justificante y santificante, que diviniza al hombre al incluirse en su armazón de criatura, confluyendo en la aceptación del hombre. Es decir, n® es sólo ofrecida como existencial sobrenatural, sino que ya opera en cuanto oferta para la aceptación del hombre. Dios sostiene la aceptación del hombre de igual

101. Escritos de Teología, I, 340, 343; «Existencial sobrenatural», en Sacramentum mundi, III, 68 .

102. Curso fundamental sobre la fe, 209.

103. Ibid. 
manera que sostiene el don, de forma que la gracia es gracia eficaz ${ }^{104}$. La gracia se convierte en gracia plena por la colaboración del hombre y es principio de la visión beatífica. Y como la gracia-revelación supone al hombre libre y todo hombre sin excepción, hay que colocar la revelación al mismo nivel apriórico que tiene la libertad en el ser humano, esto es, es trascendental.

La revelación trascendental es lo mismo que la fe trascendental y atemática que informa el espíritu del hombre, que es necesaria como presupuesto de la revelación exteriorizada, por el que el hombre puede reconocer en un hecho histórico la acción salvífica de Dios y luego expresarla como tal. El horizonte sin límites del conocimiento humano está marcado desde su origen por el autoofrecimiento de Dios, que le influye y toca a lo largo de su desarrollo.

La revelación trascendental es la salvación que Dios ofrece a todo hombre. Dios como Padre concede la gracia de su amor a todos, invitándoles a participar de su ser en la consumación plena de las posibilidades del hombre. Dios se revela como gracia que quiere la salvación del hombre y que provoca la aceptación del hombre de esa salvación. La voluntad salvífica de Dios dentro del hombre no se desvanece con el rechazo humano. El amor de Dios es más fuerte que el pecado e insiste como ofrenda inquebrantable ante el pecador, buscando su conversión. Dios por la revelación en que se entrega absolutamente al hombre no es la lejanía rehusante que podría ser en su radical misterio y perfección, sino la cercanía total e indulgente que colma la ilimitación espiritual del hombre e inicia la salvación ${ }^{105}$.

c) Revelación categorial.

La revelación trascendental como comunicación absoluta de Dios reclama al hombre entero, no se dirige a una facultad particular de él. El hombre es fundamentalmente espíritu en la materia, intrínsecamente unidas y mutuamente condicionantes, en forma tal que el hombre no llega a la consciencia de su espíritu, y así lo realiza, más que dependiendo de la materia, y no delimita en su concretez a la materia más que por el desbordamiento que de ella hace el apriorismo de su espíritu. La síntesis que es el hombre de espíritu y materia se llama también historia: El hombre es historia. El ser historia del hombre es el desenvolverse de su espíritu libre en el mundo material, por el que está condicionado y al que, a la vez, supera. La libertad del hombre actúa en el mundo, no puede hacerlo de otro modo y ahí vemos su dependencia; pero, supuesta la base en que debe maniobrar, la libertad no es controlable por esta base, a pe-

104. Ibid., «Gracia» en Sacramentum mundi, III, 322. Rahner resalta esta aceptación del hombre como soportada y causada por Dios. Pero no puede decirse que ignora al hombre como libre y la posibilidad de rechazo a la revelación.

105. Curso fundamental sobre la fe, 209; Escritos de Teología, IV, 79. 
sar de que la limite; puede moverse imprevisiblemente dentro del cauce en que se encuentra.

La revelación de Dios destinada al hombre uno está destinada al hombre como historia, tiene lugar en la historia humana. La revelación trascendental, presente desde siempre en el apriorismo espiritual del hombre, no llega a ser consciente, no se encuentra a sí misma en el hombre, sino partiendo de lo material del mundo. El espíritu humano tornaba en sí mismo sabiendo de sí mismo cuando salía de sí identificándose con la materia, y así también la revelación trascendental deberá hacerse sensible, deberá expresarse en el mundo para saber de sí como revelación. En palabras de Rahner: la trascendentalidad apriórica del hombre está mediada consigo misma a través de su experiencia aposteriórica y conceptual, y la trascendentalidad apriórica elevada sobrenaturalmente estará también mediada consigo misma a través de su experiencia aposteriórica y conceptual ${ }^{106}$. Es decir, la revelación trascendental en el espíritu del hombre no es conocida por él sino a partir de la revelación categorial que él expresa en su historia.

La revelación trascendental está desde siempre en el espíritu del hombre como un existencial apriórico de su ser, donde en princpio no sería reflejo o sabido. Pero el espíritu del hombre no existe en manera pura en la realidad, sino siempre vertido en el mundo, realizándose a sí mismo en la historia. Del mismo modo la revelación trascendental en el interior humano no se mantiene en sí misma en modo puro, sino que se implica necesariamente en el mundo, en su realidad acontece siempre en la historia, se exterioriza en lo material y llega así a saber de sí misma. La revelación trascendental desemboca obligatoriamente en la exteriorización categorial con que el hombre tematiza su portada interior al conectar inevitablemente con lo sensible exterior.

El hombre, espíritu trascendente que encierra en sí un saber apriórico sobre Dios, por la autodonación de Dios, es medularmente un ser histórico, y su saber sobre Dios será necesariamente autointerpretado de modo histórico, lo cual es la revelación histórico-categorial ${ }^{107}$. Este momento categorial, interpretación conceptual de la revelación trascendental que necesariamente la prolonga o, mejor dicho, la hace explícita, puede, por ese motivo, ser llamada también revelación. La revelación categorial no se reduce a una introspección e interpretación externa del hombre solo, sino que forma parte de la dinámica interna de la autorrevelación trascendental de Dios al hombre histórico, que por ello será volcada en conceptos historificantes. La interpretación categorial que el hombre hace de su divinización trascendental es posible porque Dios se

106. Curso fundamental sobre la fe, 187.

107. Ibid., 189. 
le ha dado y por tanto, en último análisis, procede del mismo Dios. Es por consiguiente revelación de Dios.

Por otra parte, si el hombre es historia que necesariamente autointerpreta su experiencia trascendental, entonces, la autointerpretación inevitable de la originaria revelación trascendental donada por Dios se conforma asimismo como historia. La historia de la revelación, consecuentemente, es la historia de la autointerpretación explícita de la revelación trascendental que el hombre tiene desde siempre y de la formulación en palabras que la seguirá ${ }^{108}$.

Y como la revelación trascendental está presente en todo hombre como elemento imprescindible de su ser, en todo hombre se decantará como revelación categorial al interpretar necesariamente su interioridad en moldes históricos. Todo hombre plasmará su apriorismo en una expresión categorial, conceptual, y más explícitamente en palabras. Pero la existencia del hombre se sitúa siempre junto a la de otros hombres, el hombre es un ser que vive y progresa en comunidad. El autoentendimiento del hombre se lleva a cabo dentro del autoentendimiento particular de los hombres con los que comparte su vida, comunidad que, a su vez, se entiende en los márgenes de una interpretación del hombre en el mundo recibida de una tradición, quizá larga y con una mayor o menor evolución interna. La autointerpretación categorial que todo hombre hace de su trascendencia participa de la autointerpretación categorial de la comunidad con que vive, o al menos es influida o toma postura propia siempre en relación con la autointerpretación comunitaria en la que se encuentra inmerso. Ésta es la revelación categorial «particular»: expresión en palabras que un pueblo o una cultura hace de la revelación trascendental ${ }^{109}$.

Antes de seguir adelante hay que confirmar la posibilidad de una interpretación por la palabra de la revelación trascendental. Esto quedó claro en la parte dedicada al lugar de encuentro entre Dios y el hombre. Se dijo que la revelación de Dios, para llegar al hombre, tenía que pasar por la materialidad de la historia. Lo material, en su finitud, no limitaba como medio el hablar de Dios al hombre, pues el hombre, que para su conocer debe partir de lo fenoménico del mundo, sabía desgajar la trascendentalidad divinizante de Dios que debía referirse a la materia mediante la negación del límite. A través de la experiencia trascendental del límite, con la negación, el hombre alcanzaba el ser de todo ente supramundano, concebía nociones por encima de la limitación fenoménica. Esta negación, dijimos, se realizaba por la palabra como re-

108. Ibid., 190; «Revelación», en Sacramentum mundi, VI, 96.

109. «En cada religión se hace el intento (al menos por parte del hombre) de mediar históricamente la revelación originaria, no refleja ni objetiva, el intento de reflexionar sobre ella y de interpretarla en enunciados» (Curso fundamental sobre la fe, 211). Para el aspecto comunitario de la revelación categorial: Ibid., 196. 
presentación, como concepto que negando lo finito suponía una afirmación sobre algo no finito. La palabra liberaba a la revelación de Dios de la estrechez de lo sensible, puente forzoso para llevarla al conocimiento humano, y la recibía en su integridad en la negación trascendente ${ }^{110}$. Por consiguiente la palabra es el medio legítimo de interpretación de la comunicación divina.

Volvamos a lo anterior. Todo hombre interpreta categorialmente la revelación trascendental que se le da como gracia. Por la estructura social del hombre, esa interpretación categorial se concreta en la comunicación y asimilación de la interpretación que se acepta en un ámbito determinado comunitario-religioso, que fija su fe en palabras al servicio de la cohesión de la comunidad creyente. Es la revelación categorial particular que se nos ofrece en el abanico de la historia de las religiones y que pocede últimamente de Dios que se dona como un existencial sobrenatural en cada hombre.

Sin embargo, la necesaria autointerpretación histórico-categorial de la revelación trascendental no significa que haya siempre una correspondencia real de la revelación categorial respecto de la trascendental divina. La situación histórica del hombre está siempre envuelta en el error y la culpa, que inducen a la equivocación y desvían la interpretación del sentido original de la revelación. Según Rahner, que la experiencia trascendental del hombre se dé en su historia de modo objetivante formando ella misma una historia categorial de la revelación, en todo lugar y tiempo en que exista el hombre, indica que, como historia, es algo en evolución, todavía no consumada, que se busca a sí misma en orden a su plenitud. La interpretación correcta categorial sólo se da parcialmente, está siempre mezclada con el error culpable, que oscurece la auténtica revelación de Dios ${ }^{111}$.

¿Cómo distinguir la verdadera y la falsa categorización de la revelación trascendental? Rahner conoce a la revelación conceptual que se corresponde con la divina como revelación categorial estricta o «especial». Será aquella que «se sabe como querida y dirigida positivamente por Dios y se cerciora de la legitimidad de este saber en la manera preceptuada por la naturaleza de la cosa (...); es el caso más logrado de la necesaria autointerpretación de la revelación trascendental $\mathrm{o}$, mejor dicho, la plena realización esencial de ambas revelaciones - la trascendental y la categorial- y de su historia una en una unidad y pureza de esencia» ${ }^{112}$. Esta revelación se da en el Antiguo y Nuevo Testamento, pero no de modo perfecto, pues ella tạmbién se halla condicionada por la fuerza de la culpa como historia que es del hombre, de manera que no se libra del error. Por otra parte, también fuera del Antiguo y Nuevo Testa-

110. Cfr. p. 40ss: parágrafo 2: palabra-representación.

111. Curso fundamental sobre la fe, 191, 211.

112. Ibid., 190-191. 
mento se puede dar esta revelación categorial especial, en momentos en que la dialéctica verdad-error de la historia humana que se autointerpreta se inclina en favor de la verdad.

Además, dada la esencia social del hombre por la que la experiencia de sí mismo se consigue siempre en la comunicación con los otros hombres, la revelación categorial especial tendrá como otra de sus características su validez en lo principal como recta autointerpretación para los hombres de todo tiempo y situación. Muchos hombres llegarán por intermedio de ella a la auténtica autointerpretación de su experiencia trascendental, pues la ambigüedad de la historia humana no permite siempre el éxito de la propia búsqueda autocrítica de conceptualización del bagaje interno. La historia categorial particular de la revelación se encuentra en una franja limitada de la espacio-temporalidad de la historia humana, junto a otras autointerpretaciones también limitadas, pero que en un futuro podrán tener una repercusión en los hombres que las reciban y las juzguen. Y en este sentido toda autointerpretación correcta de la revelación trascendental que se alberga en todo hombre tendrá validez teórica para todos los hombres, lleva en sí misma, aunque tal vez no lo sepa, un movimiento hacia el universalismo, para una mediación progresivamente mejor de la autointeligencia del hombre. La historia particular especial de la revelación será una etapa preeminente, en su pureza, dentro de la historia general de la revelación y salvación ${ }^{113}$.

La historia de las religiones no cristianas no es una simple revelación natural del hombre sino que está sostenida por el Dios que se entrega a todos y no discurre sólo por caminos extraviados sino que también tendrá elementos de recta interpretación categorial. Y esto no atenta contra la absolutez del cristianismo como única revelación auténtica — también con momentos erróneos-, consciente de estar guiada por Dios, porque lo positivo de otras religiones coincidirá con la esencia de la autointerpretación cristiana, en la funcionalidad universal de toda revelación categorial auténtica ${ }^{114}$.

d) Jesucristo.

Ya que el tema que estamos tratando versa sobre la apertura del hombre a la revelación divina y la capacidad del hombre para reconocerla como tal, y, como complemento, el hecho de la revelación en general en la historia del hombre y su consiguiente autointerpretación refleja, no concierne aquí expo-

113. Ibid., 197-198, 212.

114. Oyente de la palabra, 233ss. y nota 10; Curso fundamental sobre la fe, 193: Se ve una cierta evolución en Rahner hacia la apertura sobre este tema entre esos dos textos pero, curiosamente, sin contradicción, en la peculiaridad rahneriana de una evolución teológica sin alterar los primeros pasos (LEHMANN, K., «Karl Rahner», en Bilancio della teologia del XX secolo, IV, 171). En este sentido que se habla en el texto se entiende la doctrina rahneriana sobre los «cristianos anónimos». 
ner particularmente el acontecimiento de Cristo como revelación suprema. Sin embargo, el hecho de Jesucristo tiene una concreta significación, según Rahner, respecto a la historia general de la revelación.

Se acaba de dejar constancia de que las distintas historias particulares de la revelación componen la única historia de la revelación, y del valor de aquéllas, cuando no son deformaciones de lo trascendental, al servicio de un mejoramiento de la historia global de la revelación. La autointerpretación histórica de la comunicación de Dios al hombre que tiene lugar en Jesucristo escapa al error histórico y no podrá ser oscurecida por ninguna interpretación categorial posterior. La autointerpretación categorial que sucede en Jesús se identifica exactamente con la revelación trascendental de Dios. La comunicación de Dios se une hipostáticamente, encarnándose, en la realidad humana de Jesús, lográndose, para él y para nosotros, el culmen de la revelación categorial, y con ello el de la revelación en general. La revelación trascendental, la donación de Dios, y la revelación categorial, la expresión historificante en el hombre Jesús, forman una unidad, son la única realidad del Logos encarnado en el hombre, y la revelación categorial es también la revelación trascendental. Es, pues, la consumación histórica de la revelación. Y si Jesucristo es la perfección de la revelación categorial, Jesucristo será el criterio para distinguir a lo largo de la historia de las religiones, dentro de la historia de la humanidad y de la historia de la revelación, lo que pertenece a una falsa interpretación de la revelación trascendental sobrenatural y lo que, por el contrario, sea verdadera autointerpretación.

Y esto no sólo para las religiones no cristianas anteriores o posteriores a Cristo. Jesucristo es también base para el discernimiento de lo que es auténtica o desfigurada interpretación de la trascendentalidad divina en el Antiguo y Nuevo Testamento. La fe en Jesucristo nos ayuda a ver lo que en la revelación veterotestamentaria responde correctamente a la manifestación trascendental en el corazón humano, y que tenderá al hecho de Jesucristo para su plenificación, y lo que se extravía durante ese recorrido. Y también lo que tras Jesús, en el Nuevo Testamento y en la tradición cristiana posterior, responde justamente a lo que nos dejó, y lo que distorsiona el mensaje de Jesús por la influencia perniciosa de la historia culpable de los hombres ${ }^{114}$.

114. Curso fundamental sobre la fe, 193-194, 212-213. Sobre el último párrafo del texto hay que decir que Rahner no habla en las citaciones señaladas del Nuevo Testamento sino sólo del Antiguo. Con todo, creo que responde a la doctrina de Rahner, que reconoce posibilidad de error en el Nuevo Testamento, confeccionado siempre por hombres que a pesar de su contacto más o menos próximo con Jesús están siempre situados en una historia que también lo es de la culpa (cfr. Ibid., 183, 191). 


\section{CONCLUSIÓN}

La intención de este trabajo ha sido ver la doctrina de Rahner respecto a la revelación, sobre todo desde el punto de vista humano. Es decir, ver la disposición del ser humano ante una eventual comunicación divina, si en el hombre hay algo que pueda contener a Dios mismo, pues él es quien se automanifiesta totalmente en la revelación, y si el hombre puede detectar esa revelación como lo que es en sus justos términos - autorrevelación de Dios- desde la estructura existencial que experimenta de sí mismo. Es una antropología teológica la que sigue Rahner ${ }^{115}$, o sea, un estudio del hombre desde la fe en Dios, Dios que en su libertad se lo puede comunicar gratuitamente.

Este hecho de que se parta de Dios para estudiar al hombre no debe pensarse como un condicionamiento apriórico de los resultados que se tengan. $\mathrm{O}$ sea, que se está con una predisposición que influirá en el análisis del ser humano y, por consiguiente, que no se logrará una neutralidad o imparcialidad en las conclusiones. Y esto porque el hombre, en la tarea de hacerse a sí mismo, en su pensar y obrar, no puede prescindir de presupuestos. El actuar del hombre en su vida, que es siempre un actuar consciente y, por tanto, pensante aunque no contenga una reflexión explícita, comporta necesariamente unos presupuestos, sin los cuales sería imposible el actuar de la libertad que es cada hombre. Toda obra del hombre se cimenta en una intención a la que la obra apunta como su finalidad. El hombre actúa para conseguir algo, sea esto inmediato o remoto. $\mathrm{Y}$ el conjunto del obrar del hombre, inseparable a su pensar, que forma su vida se funda igualmente en una intencionalidad que, tomada en conjunto, tiene por meta la propia autorrealización. O sea, que el proceso vital del hombre sería impensable sin presupuestos. Y lo mismo debe decirse de una reflexión concreta, que es en resumidas cuentas un actuar del hombre que busca como fin último una comprensión de su existencia. Toda reflexión humana se fundamenta inevitablemente en una búsqueda del sentido de la vida, el cual es presupuesto, al menos como esperanza, para no hacer inútil esa reflexión. Y esa esperanza de sentido, que solamente la da Dios, es una intuición irrefleja de todo hombre. El actuarse del hombre, en su pensar y obrar, es una apuesta esperazada en la existencia de Dios. Rahner, entonces, al comenzar su reflexión presuponiendo a Dios, no hace más que explicitar la decisión implícita de toda reflexión. El que ese presupuesto sea explícito y no implícito no condiciona los resultados de su análisis sino sólo la aplicación final de las conclusiones. Al no tener ese presupuesto explícito las conclusiones quedrían en el aire buscando sujección. Para optar por Dios y apoyarlas en él

115. Oyente de la palabra, 221. 
se requiere la fe, que afecta a las concluiones hechas pero no necesariamente a su proceso de formación.

La reflexión del hombre sobre sí mismo intenta cerciorarse de la validez del presupuesto que no puede soslayar, si responde a una realidad o es un amargo espejismo. Puede darse el caso de que tras una concienzuda indagación llegue a convencerse de que la esperanza de sentido que le ha empujado a ello sólo sea un doloroso vacío, aunque el seguir viviendo mostrará que queda una desesperada esperanza en la victoria del sentido. El existencialismo filosófico moderno prueba esto. Trata de averiguar qué hay de verdad en la esperanza humana de un significado del mundo. La conclusión es negativa, el sinsentido. La angustia y náusea que este descubrimiento produce demuestra hasta qué punto está arraigada la esperanza en el hombre. Concluyendo: el vivir actuante del hombre es posibilitado por una intuición presupuesta que podemos llamar, resumiendo, la afirmación de Dios. Razonar sobre algo basándonos en ese presupuesto, que por otra parte no se puede eliminar inconscientemente, no condiciona las deducciones del razonamiento, puesto que pueden ser contrarias a él. El estudio que Rahner emprende sobre el hombre suponiendo a Dios es, por consiguiente, legítimo.

Rahner observa al ser humano en su autoexperiencia. Una característica de la estructura humana que brota de la propia experiencia es la peculiaridad espiritual del hombre, exclusiva de él en este mundo fenoménico, que le convierte en el ser más perfecto de la creación. El distintivo espiritual del hombre se refleja en su consciencia, en su facultad de pensar, juzgar y obrar según su pensamiento, con una libertad no condicionada en sus concreciones, sino sólo en su existencia, por el mundo ${ }^{116}$. En el funcionamiento de su conocimiento y libertad, que son lo mismo en la consciencia subjetiva una del hombre, Rahner veía que el espíritu del hombre retornaba a sí misma después de tener que referirse necesariamente a las cosas sensibles del mundo, diferenciándose de ellas y aprehendiéndolas como cerradas o acabadas en sí mismas. En una reflexión posterior el hombre se daba cuenta de que si conocía las cosas como finitas y él quedaba aparte - aunque experimenta en sí la finitud porque él es mundo - sería porque tenía una idea interna de la infinitud, lo cual le posibilitaba la percepción de los límites de los objetos materiales. Esa infinitud no puede ser finita, no tenderá hacia la nada sino hacia Dios. Con ello Rahner dejaba sentado la apertura absoluta del hombre a la infinitud de Dios.

116. Rahner tiene razón al pensar que, al menos teóricamente, la libertad es imprevisible. Un acto libre en la práctica está en cierta manera condicionado por unas circunstancias. Pero si partimos de la libertad como facultad humana vemos que podría haberse concretado, manteniéndose las mismas circunstancias, en un acto distinto. La libertad está por encima de las circunstancias. Si, por el contrario, se parte sólo del acto concreto únicamente se verá como condicionado. 
Ya se comentó la problemática de esta conclusión de Rahner. De un lado no era algo evidente por sí solo. El hombre siente que es algo más que este mundo, tiene fe en que ese algo más que la hace ser distinto y superior a todo responda a una realidad. Pero no lo puede saber con certeza, no sabe si esa infinitud que compone su personalidad es, a fin de cuentas, Dios. La infinitud del espíritu humano se entiende como algo que supera todo lo sensible, que no está limitado en comparación con la concretez de las cosas materiales; es algo con una amplitud indefinida, pero no sabe hasta dónde llega, si conecta con la infinitud divina. Además, Dios es un presupuesto de fe. Dios rebasa la materialidad de que depende el hombre y por ello no puede ser demostrado empíricamente. Por lo tanto, considerar la tendencia a la infinitud del espíritu humano como algo absoluto e identificarla con Dios, al menos genéricamente, sobrepasa el saber seguro del hombre. Es una decisión de fe y esperanza. Pero es una decisión tremendamente lógica. Es decir, el hecho de que la conclusión de Rahner se apoye en una desición del hombre no es algo negativo. Responde a la misma esencia del hombre que se compone de esperanza. La deducción de Rahner no es evidente en sentido matemático, pero no es irracional, antes bien, tiene toda la fuerza de ser algo que responde exactamente a la estructura del hombre, una de cuyas características es la razón, y en consecuencia, responde a las exigencias de su racionabilidad esperante o esperanzada. No se puede negar la validez incontestable de una adhesión de la razón humana a la esperanza de que su trascendencia se dirija a algo absoluto - que sería identificado con el Dios de la fe- porque la esperanza, al fin y al cabo, es lo que sostiene al ser humano en su existencia.

Esta conclusión de Rahner es muy importante. En ella se basa toda su disquisición ulterior sobre la aptitud del hombre para una revelación de Dios. En efecto, una vez aclarada la infinitud trascendente de la razón humana se deduce como principio su correspondencia perfecta a la autodonación de Dios, aunque haya que salvar la también constitutiva materialidad del hombre. Toda la argumentación subsiguiente de Rahner que intentará detallar el cómo de esta receptibilidad positiva del hombre ante su Dios participará de la evidencia lógica ${ }^{117}$ del punto de partida, si lo sigue, como diremos, con una coherencia interna; pero a la vez participará de su no evidencia matemática, los resultados que consigue Rahner no pueden definirse como irrebatibles ante toda razón y decisión del hombre.

La experiencia de su propia infinitud el hombre la ve como no sostenida en sí misma. La trascendencia absoluta de su espíritu se realiza como tal, llega

117. Así creo que se entiende la denominación que Rahner aplica a Dios como «lo obvio, evidente» (Curso fundamental sobre la $f e, 40$ ), aunque puede parecer excesiva. 
a sí misma, desde la materialidad sensible. Que el hombre conozca las cosas en cuanto finitas le indicaba que su conocer tenía una cierta noción de lo infinito. Pero esa noción de lo infinito no se le haría presente a su conciencia si no conociera las cosas que se le enfrentan en su mundo. El hombre se encuentra siempre en el mundo; ese mundo sensible lo capta en su limitación porque su a priori mental lo desborda, pero este su desbordar el mundo sólo lo sabe a posteriori, una vez que lo ha cumplido, es decir, después de encararse con el mundo. Por tanto, la absoluta no limitación del espíritu humano no existe en sí misma sino como concepto; en realidad, en la existencia, está condicionada por su contacto con lo material. En consecuencia, Rahner dice que la perfecta capacidad de la espiritualidad humana para el ser de Dios, y su consiguiente saber sobre él, no es real más que en su conexión con el mundo; el saber sobre Dios depende del saber sobre el mundo, no es directo y exhaustivo, sino indirecto, con la inseguridad de la negación. Dios es el misterio libre y el hombre sólo puede esperarlo en su acción favorable.

Esta dependencia de lo finito la percibe el hombre radicalmente en su propio ser. El hombre es, además de espíritu, intrínsecamente materia. El hombre surge de la naturaleza, existe en un determinado espacio y tiempo naturales y retorna finalmente a la materia de donde ha salido. El cuerpo del hombre es naturaleza y está sometido a las leyes de la naturaleza. El espíritu del hombre existe en indivisible unidad con su cuerpo, recíprocamente se condicionan y se posibilitan en su particularidad diferenciadora. Esta síntesis de espíritu y materia que es el hombre y la autoactuación existencial de esa síntesis Rahner la llama historia. El hombre vive «en» la historia, en el mundo informado por la libertad de los hombres, y «como» historia, como espíritu en la materia. El hombre vive en un determinado espacio y tiempo del curso de la historia, no sólo de la naturaleza, en la que el hombre se inserta necesariamente como ser esencialmente social y dependiente de los otros. Así pues, la comunicación de Dios al hombre, a la que está abierto, pero que sólo puede esperar, tendrá lugar en la historia. El componente material limitado que constituye la historia del hombre no significará una restricción a la manifestación absoluta de Dios, porque el componente espiritual la recogerá de esa materia que es punto de partida del conocer consciente y la asimilará en su plenitud, en lo que es infinitud divina, mediante la negación de la finitud sensible. Esta negación, que lleva consigo una simultánea conceptualización afirmativa, es la palabra humana. Por consiguiente, la automanifestación comunicativa que Dios puede hacer de sí mismo accede al hombre en la palabra humana.

Como puede verse la coherencia del hilo discursivo de Rahner es irreprochable. Posiblemente resultará poco admisible para hoy fundamentar el estu- 
dio de las cosas que están a la base del desarrollo rahneriano de la antropología teológica, como el conocimiento y la materialidad (espacialidad y temporalidad) del hombre, en la sistemática tomista. Pero la ciencia moderna, con ser diferente, no deja de coincidir con los resultados más significativos que Rahner toma de la escolástica en el estudio del conocer y del ser intrínsecamente material, y espiritual, que es el hombre. Rahner ha ido mostrando, basándose en la experiencia del hombre sobre sí mismo y profundizando a continuación en las consecuencias lógicas de esa autoexperiencia, la validez antropológica de una teología de la revelación. Rahner hace inteligible que se pueda hablar de revelación, explica cómo el ser humano no supone trabas a una posible comunicación de Dios.

Rahner ha demostrado racionalmente que la realidad creada una del hombre es apta para la revelación de Dios. Pero contando con la misma razón humana como instrumento de estudio no se puede asegurar el hecho de la revelación de Dios al hombre. De hecho, Rahner, en el libro «Oyente de la palabra», que es el que se centra en la posibilidad del hombre para escuchar la revelación, comenta siempre la revelación como posible. La revelación de Dios no se puede demostrar como tampoco Dios se puede demostrar, ya se dijo. Es un apartado de la fe, y la fe es creer, confiar, tener la seguridad puesta en la realidad de algo de la que, a pesar de todo, no se puede estar completamente seguro. Dios es misterio, es inexpugnable en su ser y en su obrar libre, y por tanto no se puede prever el obrar de la libertad divina en una automanifestación, aunque, si se produce, el hombre podrá captarla. Con todo, seguirá sin poder demostrarse con certeza que ese hecho pertenece a una manifestación divina, porque la luz sobre la revelación la da la luz de la fe.

Para hablar del hecho de la revelación divina Rahner tiene que acudir a la fe. La fe de la tradición católica, como universal, contiene la firme convicción - siguiendo la enseñanza de quien es su origen, Jesús- de que Dios quiere la salvación de todos los hombres. Voluntad salvífica universal es revelación universal, pues el hombre decide su salvación con su libertad, y como no hay libre decisión sin conocimiento anterior de aquello sobre lo que recae, Dios debe hacerse cognoscible a todos los hombres. Rahner infiere que Dios se revela en el interior de cada hombre. Todo hombre posee la autodonación con que Dios le llama a la salvación en el material apriórico de su ser, que durará tanto cuanto dure su vida, como existencial permanente. Es la revelación trascendental, que surge de la libertad de Dios. Corresponde a la revelación natural que forma la estructura creada del hombre como abierto a Dios, como espíritu siempre en la materia. El hombre es historia, es decir, una vez más, espíritu que se actúa en la materia, y por tanto, la revelación trascendental incluida atemáticamente en el espíritu humano se actuará en la materia, se exterioriza- 
rá y tematizará en palabras (revelación categorial) representando la originaria revelación - aunque no hay que olvidar el factor de la culpa-, pues ya se dijo que la palabra humana era el lugar de encuentro entre el hombre y Dios. El hecho de la revelación trascendental, que es sabido por la fe, completa o consuma la expectativa antropológica capaz de Dios que Rahner atribuyó al hombre racionalmente. La fe es el complemento de la razón.

Sobre el hecho de la revelación, es concebido por Rahner en «Oyente de la palabra» ${ }^{118}$ como una acción de Dios que, puesto que debe hacerse historia humana para ser captada por el hombre, se integra en un punto de la espaciotemporalidad de la historia de los hombres, al cual se dirigirá la mirada humana para encontrar el mensaje de Dios. Rahner aquí parte del presupuesto de la revelación como cumplida en el hecho de Jesucristo. El problema que deja sin resolver es el de si todos pueden conocer ese punto de la historia humana. En "Curso fundamental sobre la fe» ${ }^{119}$ Rahner resuelve esta cuestión entendiendo la revelación como algo universal, escondido en la subjetividad humana. La revelación no se concreta en un punto de la historia humana sino que se extiende a lo largo de ella, coexistiendo la historia de la revelación y la historia de la humanidad. La historia de la revelación trascendental es necesariamente objetivable en revelación categorial, con mayor o menor acierto, y halla su punto de coincidencia en el hecho de Jesucristo, que será criterio de la validez categorial respecto a su fuente trascendental. Se da una diferencia entre los dos modos de concebir la revelación: uno concierne a un momento de la historia universal y otro a cada historia particular como autointerpretación de la propia trascendentalidad divina. Sin embargo hay entre las dos una cierta continuidad: como en la primera en la segunda hay también un punto espaciotemporal predominante de revelación, donde el Dios donado a todos se encarna en una historia humana siendo uno con ella, resultando el momento culminante de la revelación. Es la evolución sin rupturas típicas de la teología de Rahner.

Karl Lehmann parece criticar a Rahner que en «Oyente de la palabra» desde el principio está suponiendo la «realidad» y la «facticidad» de la revelación cristiana y luego trata de legitimarla ${ }^{120}$. Rahner habla siempre de una revelación «eventual» de Dios y no dice real, aunque sin duda la revelación cristiana como ya cumplida no puede dejar de influir en su filosofía. Con todo

118. Oyente de la palabra, 208-216.

119. Curso fundamental sobre la fe, 177, 188-194.

120. LEHMANN, K., «Karl Rahner», en Bilancio della teologia del XX secolo, IV, 162. Otra crítica de Lehmann, más bien positiva, es que el peligro latente de idealismo en Rahner es evitado al mantener radicalmente la finitud de la existencia del hombre (Ibid., 163). 
habría que preguntarse si la revelación que Rahner supone, no ya como real sino como posible, es un presupuesto válido, que no preanuncia las soluciones. Ya dijimos que no se puede evitar tener a Dios como presupuesto, sea consciente o no, y que ello no condiciona unidireccionalmente las consideraciones finales que puedan aparecer. Y si Dios es el Dios de la esperanza del hombre, será un Dios que puede contactar con el hombre, mostrársele, de modo que colme su esperanza. Sobre esto se basa el ser de las religiones del hombre ${ }^{121}$. Así pues, Dios como esperanza del hombre, que puede actuar en su favor, pertenece al esperar trascendental que conforma la entelequia humana, y será no sólo legítimo sino inevitable punto de partida. El ensayo de Rahner ha querido justificar la validez de ese presupuesto, si es o no realizable, respondiendo afirmativamente: desde el hombre la revelación es posible, pues está abierto a ella; desde Dios la revelación es posible por su libertad salvadora, pero no sólo como posibilidad abstracta, sino como posibilidad exigida para la autocomprensión del hombre, exigencia que le viene de la divinización subjetiva de Dios y no de la sola naturaleza humana, siendo, por tanto, gratuidad divina.

Otra crítica que se hace a Rahner es que su método trascendental, al estudiar el funcionamiento del conocer humano, se refiere sólo a los objetos del mundo y olvida las relaciones interpersonales ${ }^{122}$. Es algo que también los discípulos de Heidegger han reprochado al maestro en su analítica de la existencia humana. Respecto a Rahner es una crítica justa, visible en «Espíritu en el mundo» y en «Oyente de la palabra», y que Rahner mismo acepta. Rahner dice que esas obras suyas son muy abstractas y permiten una concreción posterior, por ejemplo en el sentido de las relaciones interpersonales, que clarifique los principios generales de ellas.

De manera que, para finalizar, hay que considerar como conseguido el intento de Rahner de fundamentar racionalmente la receptividad del hombre ante una eventual revelación divina. Karl Rahner mediante un estudio filosófico de la estructura del hombre abre el camino a la legitimidad de una teología de la revelación. Dios y su actuar hacia el hombre siguen siendo objeto de fe, pero si la fe humana es fe que intenta comprenderse, fe que busca su inteligibilidad, porque el hombre es racional, el hombre no puede renunciar a pensar con su razón sobre Dios. El hombre trata de razonar su fe para creer honestamente; no puede creer sin su razón porque ello es negarse a sí mismo. La razón contribuirá a la pureza de la fe; el hombre cree, confía, cuando su mente le dice que no es absurdo. Rahner parte de la fe, como toda la filosofía cristiana, y

121. Oyente de la palabra, 146.

122. RAHNER, K., La grazia come centro dell'esistenza umana, 30-31. 
quiere hacerla inteligible en lo que toca al hombre, para reforzar la decisión que supone la fe. El hombre está abierto a la comunicación divina, concluye; la fe en Dios que se revela, sin traer una evidencia, se autocomprende como racional, y conforta la decisión fiducial del hombre entero.

Tomás MARCos MARTíneZ

Università Gregoriana de Roma 